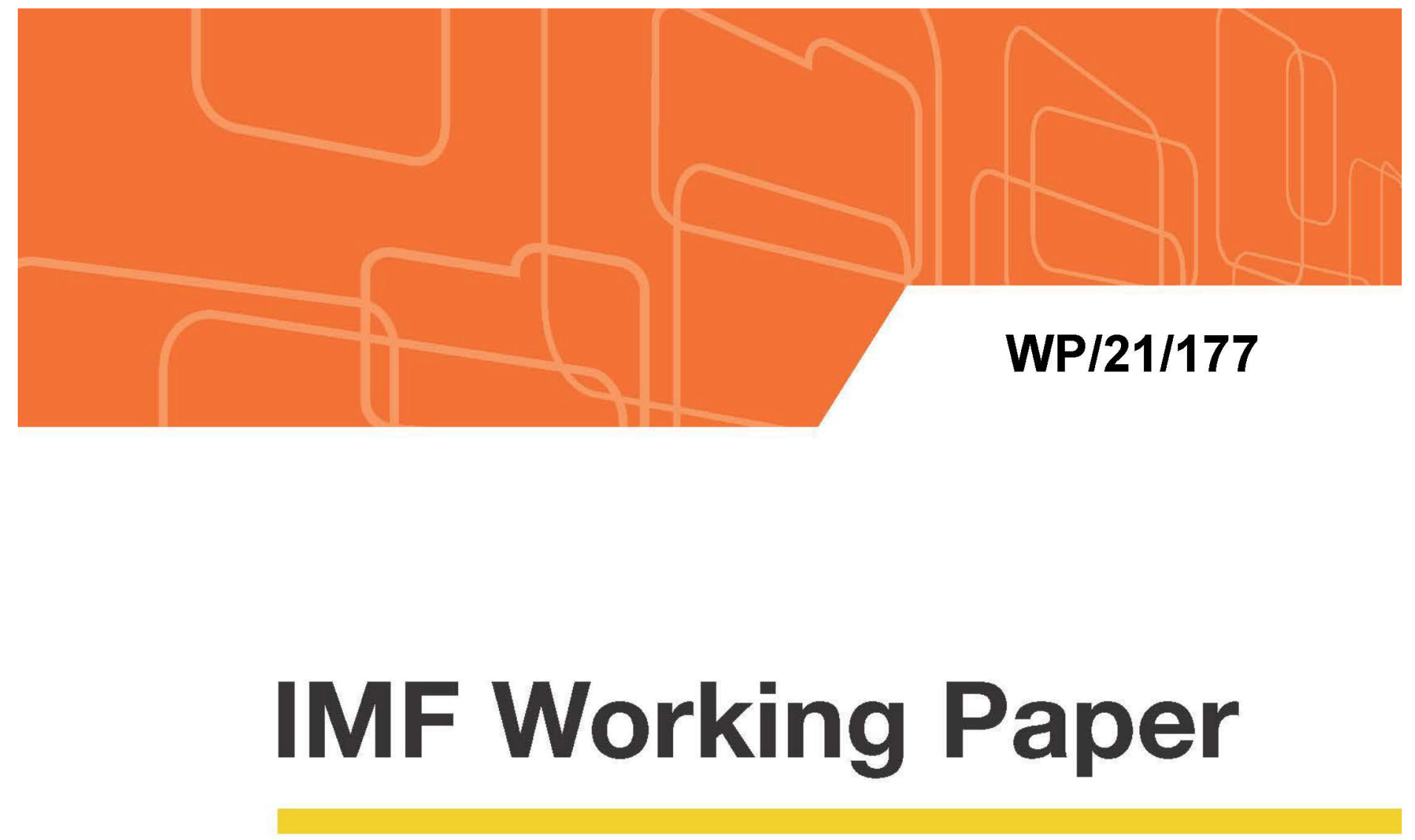

\title{
Is Mobile Money Part of Money? Understanding the Trends and Measurement
}

Kazuko Shirono, Bidisha Das, Yingjie Fan, Esha Chhabra and Hector Carcel-Villanova

IMF Working Papers describe research in progress by the author(s) and are published to elicit comments and to encourage debate. The views expressed in IMF Working Papers are those of the author(s) and do not necessarily represent the views of the IMF, its Executive Board, or IMF management. 


\title{
IMF Working Paper
}

Statistics Department

Is Mobile Money Part of Money? Understanding the Trends and Measurement Prepared by Kazuko Shirono, Bidisha Das, Yingjie Fan, Esha Chhabra and Hector Carcel-
Villanova $^{1}$ Authorized for distribution by Marco Espinosa-Vega

July 2021

IMF Working Papers describe research in progress by the author(s) and are published to elicit comments and to encourage debate. The views expressed in IMF Working Papers are those of the author(s) and do not necessarily represent the views of the IMF, its Executive Board, or IMF management.

\begin{abstract}
The rapid uptake of mobile money in recent years has generated new data needs and growing interest in understanding its impact on broad money. This paper reviews mobile money trends using mobile money data from the Financial Access Survey (FAS) and examines the statistical treatment of mobile money under the IMF's Monetary and Financial Statistics (MFS) framework. MFS guidance is straightforward in most cases, as many jurisdictions have adopted regulations which ensure that mobile money is captured in the banking system and thus in the calculation of broad money. However, in cases where mobile network operators (MNOs) act as niche financial intermediaries outside the banking regulatory perimeter and are allowed to invest their customer funds in sovereign securities and other permitted assets, mobile money liabilities may remain outside the banking system as well as monetary statistics. In that case, information on mobile money liabilities need to be collected directly from MNOs to account for mobile money as part of broad money.

JEL Classification Numbers: E42, E50, G28, M48, K20.

Keywords: mobile money, financial inclusion, fintech, economic development, monetary and financial statistics, Financial Access Survey.

Author's E-Mail Address: KShirono@imf.org, BDas2@imf.org, YFan2@imf.org, EChhabra@imf.org, HCarcelVillanova@imf.org

\footnotetext{
${ }^{1}$ We would like to thank Joseph Crowley, Elizabeth Holmquist, Mahmut Kutlukaya, Lusine Lusinyan, Justin Matz, Maria Soledad Martinez-Peria, Rita Mesias, Jose Carlos Moreno-Ramirez, Jan Nolte and Ryan Rizaldy for their insightful comments. We thank Tonia Takyi and Brian Bowling for their administrative support. This paper also received valuable comments from the Bank of Botswana, the Central Bank of Nigeria, the South African Reserve Bank, and the Bank of Zambia. The views expressed in this Working Paper are those of the authors and do not necessarily represent the views of the IMF, its Executive Board, or IMF management.
} 


\section{CONTENTS}

ABSTRACT

I. INTRODUCTION

II. MOBILE MONEY: STYLIZED FACTS 7

A. What is Mobile Money? 7

B. Trends and Developments $\underline{8}$

III. MOBILE MONEY ECOSYSTEM 14

A. Mobile Money Value Chain and Business Models 15

B. Regulations to Safeguard Mobile Money Customer Funds 18

IV. MOBILE MONEY AND MONETARY AGGREGATES 20

A. Treatment of Mobile Money in Monetary Statistics $\underline{22}$

B. Compilation of Mobile Money Data for Monetary Statistics $\underline{23}$

C. The impact of mobile money on broad money composition $\underline{29}$

V. CONCLUSION 30

\section{BOXES}

1. Mobile Money Usage Patterns: Evidence from M-Pesa Transactional Data 13

2. Narrow Bank Model-Payment Banks of India 17

3. Institutional Units and Sectors in Macroeconomic Statistics $\underline{20}$

4. Standardized Report Forms (SRFs): 1SR, 2SR, 4SR, and 5SR 21

5. Additional Treatments of Mobile Money in MFS Reporting $\underline{26}$

\section{FIGURES}

1. Mobile Money Agents are Dominant Access Points in Many Developing Economies___ $\underline{9}$

2. Mobile Money Accounts are Widely Adopted in Many Economies___ 10

3. Mobile Money Usage Has Grown Over Time __ 11

4. Mobile Money Balances are Growing Over Time ___ 12

5. Mobile Network Operator-Led Mobile Money Models Dominate in Most Regions __

6. Treatment of Mobile Money in MFS ___ $\underline{28}$

7. Mobile Money Account Balances and Bank Deposits___ $\underline{30}$

\section{TABLES}

1. Mobile Money Data Collected in the FAS $\underline{8}$

2. Mobile Money Value Chain: Key Components 16

3. Select Examples Allowing MNOs to Invest in Other Liquid Assets 19

\section{REFERENCES}

References

\section{ANNEXES}

I. Data Sources for Mobile Money $\underline{35}$ 
II. Analysis of Transaction-level M-Pesa Data

III. SRFs and Compilation of Monetary Aggregates under the MFSMCG 40

IV. IMF's Monetary and Financial Statistics Database 


\section{INTRODUCTION}

The fast pace of economic digitalization in the financial sector is changing the way people access and use financial services, with new digital financial products and platforms emerging rapidly. These changes have prompted analysts, policymakers, and statisticians alike to seek new data sources and explore various approaches to systematically classify, measure, and record fintech related activities to evaluate their trends and support policy analysis (Cornelli et al., 2020; Adrian and Mancini-Griffoli, 2019; Claessens et al., 2018).

Mobile money is an early front-runner of such fintech innovations. It is a financial service using mobile money accounts typically offered by a mobile network operator (MNO) or another entity in partnership with an MNO. Unlike mobile banking, which is the use of an application on a mobile device to execute banking services, a bank account is not needed to use mobile money services-the only device required is a basic mobile phone.

Mobile money has had a profound impact on the financial sector landscape in low- and middle-income economies, providing traditionally unbanked populations with secure and convenient means to carry out financial transactions and furthering financial inclusion (IMF, 2019a; Espinosa-Vega et al., 2020). While Africa is often considered as the epicenter of mobile money, the usage of mobile money has also grown significantly in other parts of the world, including Asia and Latin America. As of 2019, there are more than a billion registered mobile money accounts over which close to USD 2 billion transactions take place daily (GSMA, 2020a).

The rapid uptake of mobile money has generated new data needs to track its trends and developments for policy purposes. Cross-country comparable data on mobile money can serve as useful inputs for policymakers in formulating and designing targeted financial inclusion policies as well as assessing and benchmarking their impacts in a broader macroeconomic context. The COVID-19 pandemic has created even greater needs in this regard as mobile money can potentially facilitate financial transactions with minimal physical contact to support economic activity (Bazarbash et al., 2020).

The growing presence of mobile money has also raised questions of whether and how mobile money is counted as part of money in the economy, and what data may be needed to ensure mobile money to be properly captured in calculation of monetary aggregates such as broad money. These questions are fundamental in understanding the underlying data used for empirical and policy analysis, particularly given the fact that monetary aggregates are among key macroeconomic variables monitored by policymakers. ${ }^{2}$ Clarifying the treatment of mobile money in monetary statistics, specifically using the IMF's Monetary and Financial Statistics Manual and Compilation Guide (MFSMCG) as a methodological framework, can offer a useful insight in this regard.

Against this background, this paper analyzes recent developments of mobile money, including trends in adoption and usage as well as business models and regulatory requirements. It then

\footnotetext{
${ }^{2}$ For example, some studies have examined empirical relationships between mobile money and monetary policy related variables such as money multipliers and broad money (e.g., Kipkemboi and Bahia, 2019; Mawejje and Lakuma, 2019; Aron et al., 2015).
} 
examines, from a statistical perspective, the implications of these developments for the measurement of monetary aggregates such as broad money. In doing so, it contributes to the growing literature on measuring digitalization in macroeconomic statistics more broadly. ${ }^{3}$

The review of the data on mobile money from the International Monetary Fund's (IMF's) Financial Access Survey (FAS), a supply-side database on financial access and use, points to the fact that mobile money now offers more access points than traditional banking services in many low- and middle-income economies, with a larger number of mobile money agents available than ATMs and bank branches. Mobile money is also widely adopted in developing economies, with the number of registered mobile money accounts being greater than that of bank accounts in some cases. The FAS data also suggest that mobile money usage measured by transaction values and volumes has increased significantly in many economies over the past years.

Mobile money services are also starting to expand to include new and enhanced products such as credit and interest-bearing savings in some countries. Transaction-level data analysis of mobile money accounts in Kenya confirms this trend and reveals the degree of penetration of these new services among mobile money users included in the study.

The methodological guidance provided by the MFSMCG on the treatment of mobile money is relatively clear-cut-mobile money liabilities, namely outstanding balances in mobile money accounts, need to be included as part of broad money in monetary statistics. However, how mobile money affects the measurement of monetary aggregates, in practice, depends on the mobile money business model and/or the regulatory framework. In most cases, the application of the guidance is straightforward as many jurisdictions have adopted regulations which ensure mobile money to be included in the calculation of monetary aggregates. However, some cases -including when regulations allow mobile money liabilities to be invested in sovereign securities or other permitted assets-require more involved steps and additional data collection to account for mobile money in compilation of monetary statistics. In these cases, compilers of monetary statistics will need to review the prevailing situation in the country and make necessary adjustments in the calculation of broad money.

The rest of the paper is organized as follows. Section II provides an overview of the latest mobile money trends in access, adoption, and usage dimensions, drawing on the FAS database which contains country-level annual data on mobile money. Section III examines mobile money business models and key aspects of mobile money regulations-important factors in understanding the treatment of mobile money in macroeconomic statistics and its impact on the measurement of money. Section IV discusses the guidance from the MFSMCG framework on how to record mobile money and clarifies its implications for calculation of money under different business models and regulatory arrangements. Section $\mathrm{V}$ concludes.

\footnotetext{
${ }^{3}$ See IMF (2018) and OECD (2020), for example.
} 


\section{Mobile Money: Stylized Facts}

Mobile money has become a preferred mode of accessing financial services particularly in countries without deep banking penetration and with limited infrastructure. It has played a significant role in facilitating financial inclusion in some of these economies. The novelty of mobile money lies in its ease of access and use. This section starts with defining mobile money and provides an overview of mobile money access, adoption and usage trends across the globe.

\section{A. What is Mobile Money?}

Mobile money is a form of mobile payment service typically offered by an MNO or another entity in partnership with an MNO using mobile money accounts. To use mobile money services, customers usually need to register with a mobile money agent-typically small, local retail stores - of the mobile money service provider and obtain an individual virtual account linked to their mobile phone number, accessible through a SIM card. A bank account is not required to use these services-the services may be accessed only with a basic mobile phone. Mobile money customers can credit funds into the mobile money account by giving cash to a mobile money agent, and in return, receive "mobile money" of equivalent amount via their mobile phone. ${ }^{4}$ They use this electronically stored mobile money to pay their bills, transfer money to their peers, etc.

Mobile money users can also withdraw the money received as salary, deposits, or payments on their mobile money accounts using a mobile money agent. More recently, some MNOs have started to expand financial services offered via mobile money, such as interest earning savings and loans. All these activities are conducted without opening a bank account or visiting a bank branch or an ATM.

The benefits of mobile money have been relatively well documented. Studies have noted that mobile money is a safe, affordable store of value and means of funds transfer for sections of population with no access to traditional financial services (Dupas et al., 2018). It has significantly cut transaction costs of money transfers and remittances (Jack and Suri, 2014). Other studies have focused on how mobile money can facilitate efficient informal risks-sharingby enabling timely transfers of money among family/community members in times of financial distress. This in turn allows households to smooth their consumption and make more efficient investment decisions (Jack and Suri, 2011; Munyegera and Matsumoto, 2016; Suri and Jack, 2016; Blumenstock et al., 2016; Jack and Suri, 2014; Riley, 2018).

While these studies based on micro-level household surveys provide useful insights at the individual country level, it is useful to examine mobile money developments in a global context to gain a broader perspective. The next subsection examines cross-country data to highlight key mobile money trends in recent years.

\footnotetext{
${ }^{4}$ If the mobile money user has a bank account, they can transfer funds to the mobile money accounts from the bank account. However, people without bank accounts can also access mobile money services.
} 


\section{B. Trends and Developments}

The analysis of this subsection draws on mobile money data from the IMF's FAS, a unique supply-side database which contains, as part of its data collection, annual country-level data on three key aspects of mobile money-access, adoption and usage.

\section{Financial Access Survey}

The FAS, launched in 2009 , has been collecting annual data on access to and use of financial services covering 189 jurisdictions with data spanning over 15 years. In 2014, the FAS introduced a mobile money module in its annual data collection exercise to gather mobile money data on seven different series with historical data dating back to 2007-the time when mobile money came into prominence after its launch in Kenya. Using these series, the FAS produces ten indicators of mobile money (Table 1). As of 2020, 79 countries (about 90 percent of countries that have mobile money services) report mobile money data to the FAS on an annual basis. The source of mobile money data in the FAS is administrative data obtained from the regulators of mobile money service providers. ${ }^{5}$

\begin{tabular}{|c|c|}
\hline \multicolumn{2}{|c|}{ Table 1. Mobile Money Data Collected in the FAS } \\
\hline \multirow[t]{4}{*}{ Access } & Registered mobile money agent outlets per $1,000 \mathrm{~km}^{2}$ \\
\hline & Registered mobile money agent outlets per 100,000 adults \\
\hline & Active mobile money agent outlets per $1,000 \mathrm{~km}^{2}$ \\
\hline & Active mobile money agent outlets per 100,000 adults \\
\hline \multirow[t]{2}{*}{ Adoption } & Registered mobile money accounts per 1,000 adults \\
\hline & Active mobile money accounts per 1,000 adults \\
\hline \multirow[t]{4}{*}{ Usage } & Value of mobile money transactions, percentage of GDP \\
\hline & Number of mobile money transactions per 1,000 adults \\
\hline & Outstanding mobile money balance on active accounts, percentage of GDP \\
\hline & Average number of transactions per active mobile money account \\
\hline
\end{tabular}

\section{Insights from the FAS Data}

The FAS mobile money data offer a cross-country perspective on mobile money trends and developments. Specifically, these data point to the following three themes on access, adoption, and usage:

First, mobile money is now more accessible than traditional banking in several low- and middle-income countries. Mobile money is a service brought to its customers by a network of mobile money agents while banks in developing economies typically rely on physical branches

\footnotetext{
${ }^{5}$ While the FAS provides supply-side annual country level data on mobile money, there are also other databases which cover a range of aspects of mobile money. See Annex I for select data sources.
} 
and ATMs. In the last decade or so, banks have also offered "agent banking" to broaden financial service provision in geographical areas not reached by bank branch networks. ${ }^{6}$ Despite such innovations by banks, in many low-and middle-income countries, the presence of mobile money agents is higher than ATMs, commercial bank branches and non-branch retail agents combined (Figure 1). For example, in Guinea, for each commercial bank branch, there are 174 mobile money agents as of 2019. Similarly, in Mali, for every commercial bank branch, there are close to 100 mobile money agents.

\section{Figure 1. Mobile Money Agents are Dominant Access Points in Many Developing Economies}

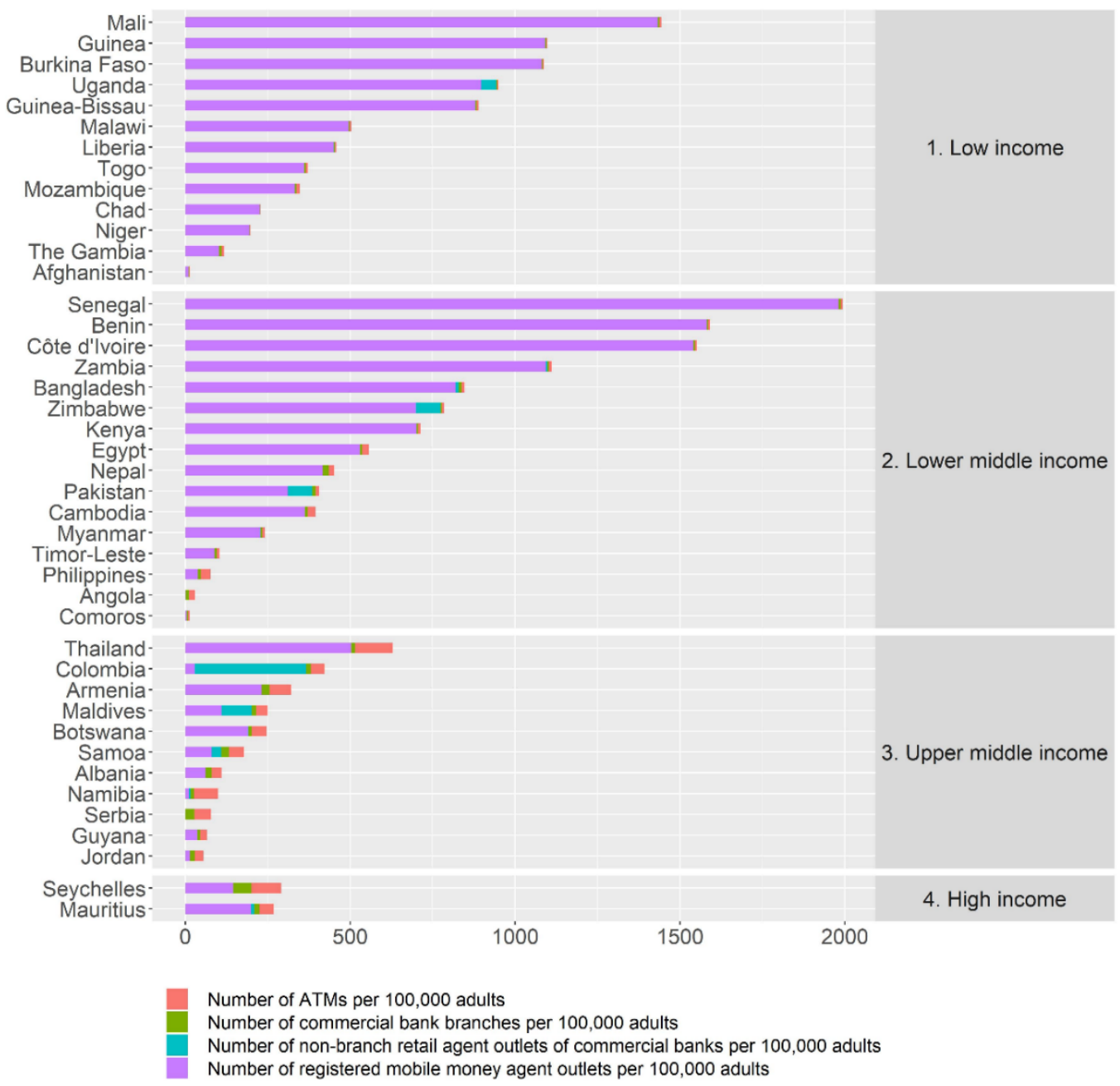

Source: IMF staff calculations and IMF Financial Access Survey.

Note: This figure shows the number of access points for mobile money (registered mobile money agent outlets) as well as for traditional banking, which includes ATMs, commercial bank branches, and non-branch retail agent outlets. Data cover 2019 or the latest year available.

\footnotetext{
${ }^{6}$ Agent banking is based on non-branch retail agents, which typically include retail stores, post offices and small businesses acting on behalf of banks to carry out financial transactions. Non-branch retail agents are different from mobile money agents. The range of financial services provided by non-branch retail agents is usually limited, often including account opening, and cash-in/cash-out transactions. These retail agent outlets are also known as "business correspondents."
} 
Second, the adoption of mobile money as a popular mode of financial access is evident in the fact that there are more registered mobile money accounts than bank accounts in several low- and middle- income countries (Figure 2). This trend is more pronounced among low-income countries. In the middle-income countries, mobile money seems to play a complementary role to traditional financial services offered by commercial banks.

Figure 2. Mobile Money Accounts are Widely Adopted in Many Economies

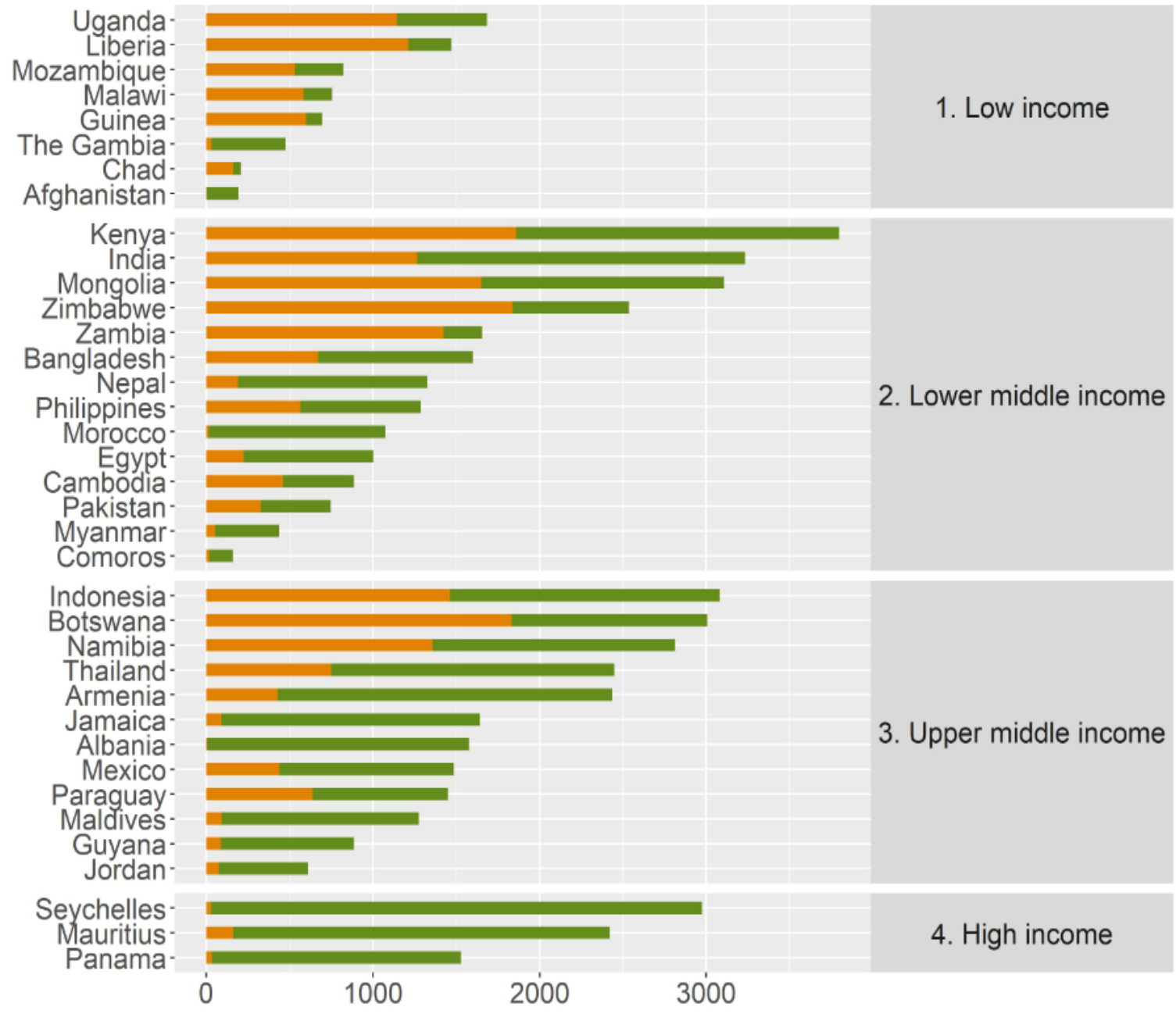

Number of deposit accounts with commercial banks per 1,000 adults

Number of registered mobile money accounts per 1,000 adults

Source: IMF staff calculations and IMF Financial Access Survey.

Note: This figure shows the number of registered mobile money accounts per 1,000 adults and deposit accounts with commercial banks in 2019 or the latest year available.

Third, mobile money usage measured by transaction values and volumes has increased significantly over time, especially among early adopters of mobile money. In line with the growing access and adoption indicators, FAS mobile money usage indicators show fast growth over the last decade for many economies (Figure 3). 


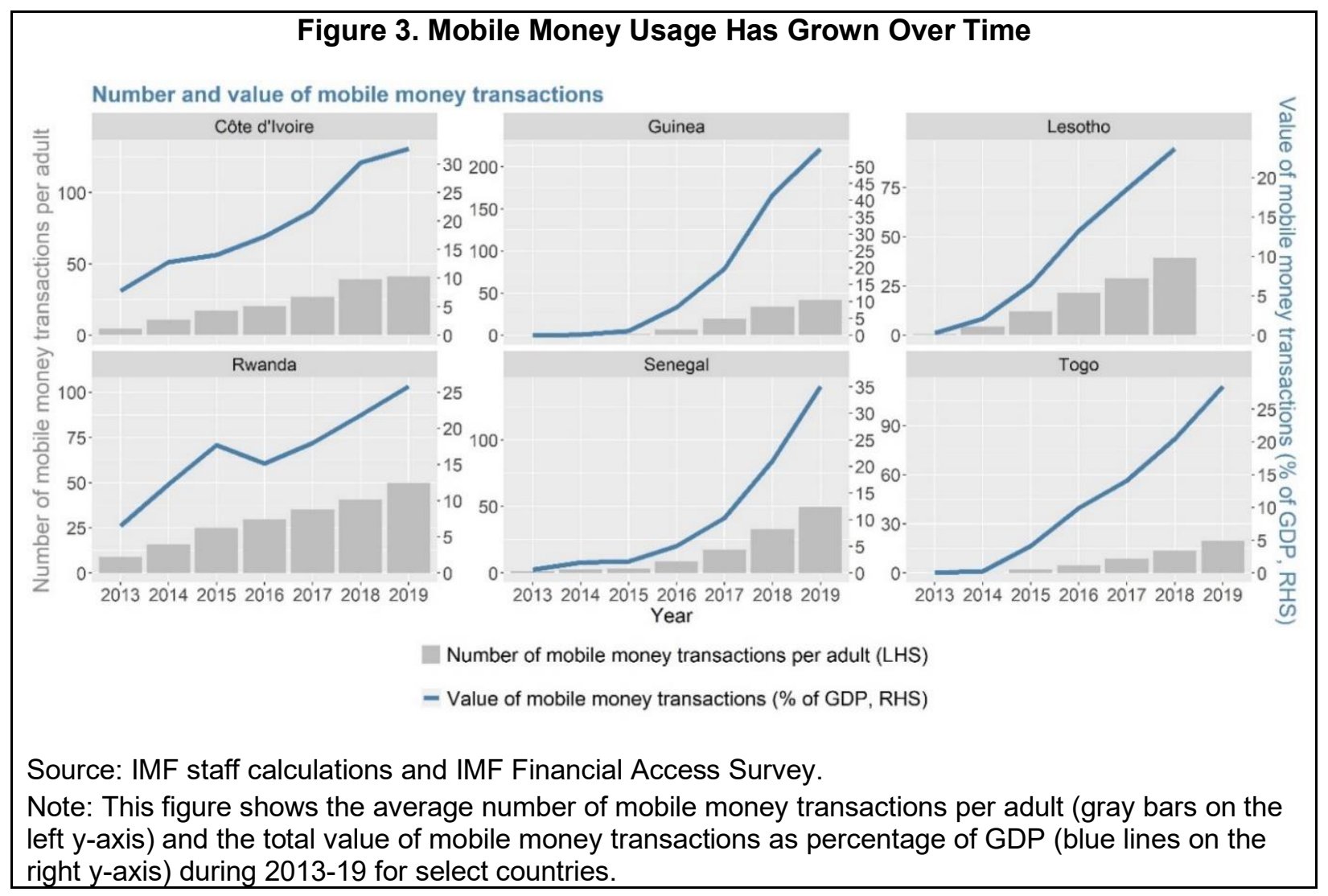

\section{New Roles of Mobile Money}

The FAS data also suggest that mobile money users have started maintaining higher balances in their mobile money accounts. Outstanding balances on active mobile money accounts can be seen as something similar to bank deposits - a sum converted from cash to mobile money but not yet used to transfer to peers or pay bills. Figure 4 shows the outstanding balances on active mobile money accounts as a percentage of GDP for select economies. The outstanding balances have risen over time, suggesting that mobile money accounts may be increasingly used as a way to store money, beyond being a mere payment platform. ${ }^{7}$

As mobile money matures, new and enhanced services including credit and insurance may be offered through the mobile money channel on a larger scale in collaboration with traditional financial service providers including insurance firms, banks, and microfinance institutions (GSMA, 2018). This trend is already seen in some of the early adopters of mobile money

\footnotetext{
${ }^{7}$ Outstanding balance over the number of users (average balance, not shown) also shows a similar trend for most countries available in the FAS.
} 
including Kenya and Tanzania, where mobile money account holders can apply for loans/microcredit through their mobile money service provider (Safaricom/Vodafone). ${ }^{8}$

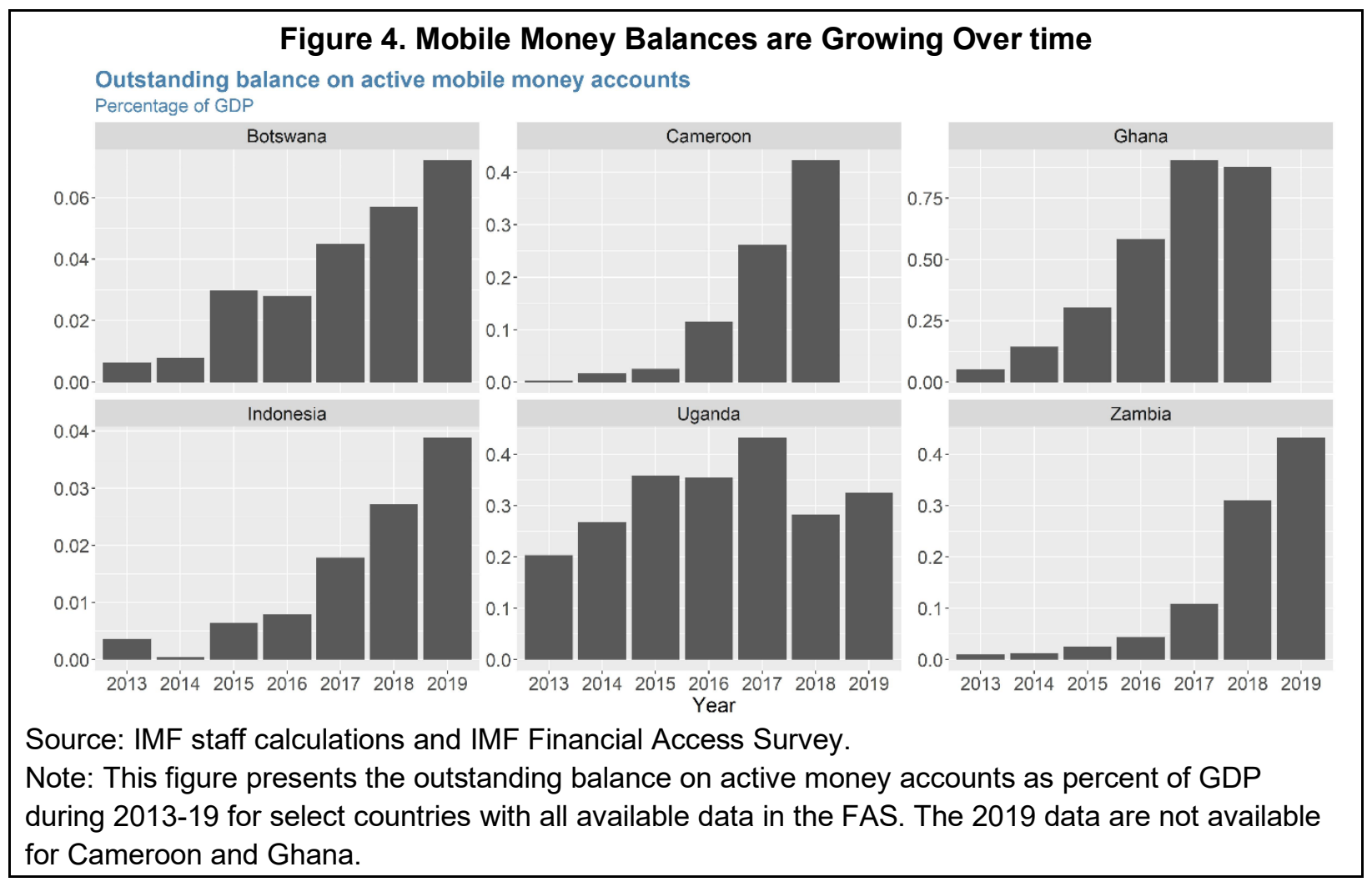

While these developments are important to monitor, data are limited and the degree of actual usage of these new services is yet to be well understood. One way to shed light on this is to draw on transaction level data. Consultative Group to Assist the Poor (CGAP) has recently made available transaction level mobile money data on M-Pesa accounts for Kenya, collected as part of a survey conducted by the Busara Center for Behavioral Economics, during the period of July 2017-August 2018 (see Box 1). While the sample size is limited, the data reveal interesting usage patterns. Specifically, the data show that mobile money users are leveraging additional financial services offered through this channel, with roughly half of the M-Pesa accounts in the study having been used for new services such as loans and interest-bearing savings.

\footnotetext{
${ }^{8}$ Other examples include Commercial Bank of Africa, a banking partner of Safaricom/Vodafone, which uses the usage history of the mobile money account to develop a credit score for the applicant, assigns individual credit limits, and decides on the application. The only way to withdraw or repay these loans is via the mobile money account. In Kenya, Safaricom's microcredit service is known as M-Shwari and in Tanzania, a similar service offered by Vodafone is known as M-Pawa. Kenya Commercial Bank Group (KCB), a financial services provider headquartered in Nairobi, also provides a savings service that enables M-Pesa customers to earn interest from their savings balance.
} 


\section{Box 1. Mobile Money Usage Patterns: Evidence from M-Pesa Transactional Data}

Given the lack of transaction level data in the FAS or GSMA, relatively little has been studied about mobile money usage patterns. Transaction level M-Pesa data made publicly available by the Consultative Group to Assist the Poor ${ }^{9}$ (CGAP) help shed light in this regard. The data consist of anonymized $418 \mathrm{M}$-Pesa accounts belonging to low-income users in Nairobi between July 2017-August 2018 (see Annex II for details). While the data may not be nationally representative, it provides important insights into the use of mobile money in Kenya, especially the usage patterns and transaction volumes and values among low-income users.

Using entity recognition and keywords extraction techniques, the transactions during the sample period were classified into eight main categories as listed in the summary table.

\begin{tabular}{|c|c|c|c|c|c|}
\hline Category & $\begin{array}{r}\text { Number of } \\
\text { transactions }\end{array}$ & $\begin{array}{r}\text { Share of total } \\
\text { transactions } \\
\text { (percent) }\end{array}$ & $\begin{array}{l}\text { Usage: } \\
\text { Number of } \\
\text { accounts }\end{array}$ & $\begin{array}{r}\text { Usage: Share of } \\
\text { total accounts } \\
\text { (percent) }\end{array}$ & $\begin{array}{r}\text { Average } \\
\text { value } \\
\text { (USD) }\end{array}$ \\
\hline $\begin{array}{l}\mathrm{P} 2 \mathrm{P} \\
\text { Transactions }\end{array}$ & 41433 & 28.07 & 416 & 99.52 & 6.6753827 \\
\hline $\begin{array}{l}\mathrm{B} 2 \mathrm{P} / \mathrm{P} 2 \mathrm{~B} \\
\text { Transactions }\end{array}$ & 33311 & 22.56 & 363 & 86.84 & 3.7215588 \\
\hline $\begin{array}{l}\text { Airtime } \\
\text { Purchase }\end{array}$ & 27992 & 18.96 & 410 & 98.09 & 0.3009765 \\
\hline $\begin{array}{l}\text { Deposit and } \\
\text { Withdrawal of } \\
\text { Funds }\end{array}$ & 26599 & 18.02 & 418 & 100.00 & 12.4832918 \\
\hline $\begin{array}{l}\text { Transaction } \\
\text { Fees }\end{array}$ & 12645 & 8.57 & 416 & 99.52 & 0.3012844 \\
\hline $\begin{array}{l}\text { Financial } \\
\text { Derivatives }\end{array}$ & 5084 & 3.44 & 202 & 48.33 & 12.2738078 \\
\hline Others & 532 & 0.36 & 187 & 44.74 & 14.9481398 \\
\hline $\begin{array}{l}\text { International } \\
\text { Transfers }\end{array}$ & 36 & 0.02 & 10 & 2.39 & 84.9181282 \\
\hline
\end{tabular}

Source: IMF staff calculations from CGAP.

Note: Usage percent of total accounts shows how many of the total accounts are being used for the type of transactions.

Key findings include the following:

- Mobile money is mostly used to conduct person-to-person $(P 2 P)$ and business-tobusiness(B2B)/person-to-business(P2B) transactions, accounting for about 28 percent and 23 percent of all mobile money transactions respectively. Unsurprisingly, all mobile money accounts carried out at least one or more P2P transactions during the sample period. The average value of such transactions is USD 6.7. More than 85 percent of accounts in the sample engaged in B2B/B2P transactions. Transaction details also reveal that M-Pesa is being used to pay salaries, which corroborates that both the public and private sectors are

${ }^{9}$ CGAP is a global partnership of more than 30 leading development organizations that works to advance the lives of poor people through financial inclusion. 
increasingly relying on mobile payment services given its low-cost nature (Wasunna and Frydrych, 2017).

- New services including credit and insurance are being offered through mobile money. Close to 50 percent of the accounts have been used for these additional financial services such as M-Shwari loans (reported under "Derivatives"-see Annex I).

- The share of international remittances is small, but the average value of such transactions is much higher, standing at USD 85, more than ten times an average domestic P2P transfer. In addition, accounts that receive international remittances carry average balances 50 percent higher than the average of those that do not receive them.

Transaction level data have great potential to unveil mobile money usage patterns and the degree of penetration of new products. Partnership with private sector entities including MNOs is key to gain further insights into mobile money usage.

In sum, mobile money has gained broader traction in many low- and middle-income economies for the past decade. At the same time, increasing usage of mobile money has prompted growing interest in how mobile money-financial services provided by MNOs-is treated in monetary statistics and how it is captured in measuring money. The following sections cover these measurement issues in detail.

\section{MobiLe Money Ecosystem}

To examine mobile money measurement issues, it is important to understand the mobile money ecosystem, including its business models and regulatory environments-key factors determining the treatment of mobile money in monetary statistics. ${ }^{10}$

A distinct feature of mobile money is the role of non-financial institutions like telecom companies in offering basic financial services to customers who would otherwise be excluded or underserved. For example, M-PESA, launched in Kenya in 2007, is operated by Safaricom, Kenya's largest telecommunication provider-a non-bank. Vodacom in Tanzania and Globe Telecom in Philippines are other examples of non-bank mobile money service providers. This mode of mobile money service provision is characterized as a "MNO-led model."

In some countries, however, banks have started partnering with third parties such as mobile network operators to offer financial services to the unbanked populations via mobile phones. This has led to the growth of a "bank-led model" of provision of mobile money services. Despite bank involvement, users do not need to have bank accounts to use these mobile money services, just as with MNO-led mobile money services.

While both MNO-led and bank-led mobile money services offer similar user experience, the mechanics of service provision under these two models are structured somewhat differently. In addition, these two models may be subject to different regulations, which have important implications for the treatment of mobile money in calculating monetary aggregates. The

\footnotetext{
${ }^{10}$ This paper mainly focuses on the mobile money business model, but other players such as merchants and regulators are also an important part of the mobile money ecosystem.
} 
following subsections provide details on mobile money business models and corresponding regulatory frameworks.

\section{A. Mobile Money Value Chain and Business Models}

Determining the type of mobile money business model starts with defining the value chain of the mobile money model. This involves identifying five basic roles to be fulfilled for mobile money service provision (Bill and Melinda Gates Foundation, 2015):

- Telecom channel provider: This is the institution which provides network access to users. This role is carried out by an MNO, irrespective of business model type.

- Agent network manager: This role is important to the success of mobile money service provision. Mobile money agents are the interface between the mobile money customers and the mobile money service provider. An extensive network of mobile money agents is considered a key driver for the penetration of mobile money among often unserved last-mile customers.

- Payment service provider: The institution carrying out this role provides the front-end interface including the phone interface for agents and customers; the back-end processing; and is responsible for clearing and settlement.

- Mobile-money issuer: This is the institution responsible for issuing mobile money. In other words, the mobile money issuer takes on the corresponding liability for issuance of mobile money - if a mobile money user wants to convert his mobile money to cash, the mobile money issuer is legally bound to provide the required funds. ${ }^{11}$

- Deposit holder: This role, irrespective of the business model, is carried out by a financial institution, typically a bank, which is responsible for safekeeping the funds deposited by mobile money customers.

What determines whether a mobile money service is MNO-led or bank-led is the type of the entity which takes on the mobile money issuance role. If a bank (or MNO) books the corresponding liability for deposits of mobile money, the mobile money service is classified as the bank-led (or MNO-led) model.

The MNO-led model can be also generalized as a "non-bank led model" as the role of mobile money issuer can be carried out by a third party (e.g., a fintech company) -in this case, it is called a "third-party led model." For simplicity, this paper focuses on the MNO-led and bank-led models and treats the third-party led model as a variant of the MNO-led model. The same statistical treatments applied to the MNO-led model also hold for the third-party led model below.

It is important to note that regardless of the business model, both banks and MNOs are essential to offer these services. While MNOs offer the telecom channel, banks hold the funds

${ }^{11}$ A liability is established when one unit (the debtor) is obliged, under specific circumstances, to provide funds or other resources to another unit (the creditor) (see MFSMCG 4.6). 
that can be converted into mobile money. MNOs and banks may also partner with other third parties to offer some of these functions (Table 2).

\begin{tabular}{|l|l|l|}
\hline \multicolumn{2}{|c|}{ Table 2. Mobile Money Value Chain: Key } & Components \\
\hline Telecom channel provider & MNO-led Model & Bank-led Model \\
\hline Agent Network manager & MNO/Third party & MNO \\
\hline Payment service provider & MNO/Third party & Bank/MNO/Third party \\
\hline Mobile money issuer & MNO & Bank/MNO/Third party \\
\hline Deposit holder & Bank & Bank \\
\hline Source: IMF staff and Bill and Melinda Gates Foundation (2015). & Bank \\
\hline
\end{tabular}

Most mobile money service providers are MNO-led (Figure 5), but MNO-led and bank-led models can also co-exist in a country. In some cases, however, regulations prohibit non-banks from operating as mobile money providers (e.g., India, Bangladesh), and some variants of these models are also possible depending on mobile money regulations of the country. Examples of mobile money business models, including variants, are as follows:

- MNO-led model: MNOs are often big telecom service providers uniquely positioned to provide mobile money services as they typically have a network infrastructure in place and brand recognition among customers. Examples include M-PESA in Kenya, M-Pitesan in Myanmar, and MTN mobile money in Uganda. A variant of the MNO-led model, although not as common, also exists wherein a third party provides the mobile money service in partnership with an MNO ("third-party led model"). Examples include OPay and Palm Pay in Nigeria, founded by a Chinese-owned internet company, Opera.

- Bank-led model: Given banks are at the forefront of offering these services as registered financial institutions, the bank-led model is sometimes considered more secure than the MNO-led model. Examples include bKash in Bangladesh, Hello Paisa in Nepal, and Eazy Money in Nigeria. A variant of the bank-led model is a narrow-bank model, wherein a new type of institution-such as payment banks in India-is created under existing banking laws and can offer a limited set of financial services (see Box 2).

Different business models are more dominant than others in different regions. Close to twothirds of the live mobile money services in Sub Saharan Africa, and Middle East and North Africa are MNO-led. On the other hand, in East Asia and Pacific and Europe and Central Asia, that number is only about one-third. These differences can be in part attributed to the legal and institutional frameworks in the region. Pelletier et al. (2020) show that MNOs are more likely to launch mobile money services in countries where legal rights are weaker and credit information is less prevalent. 


\section{Box 2: Narrow Bank Model-Payment Banks of India}

In India, non-bank e-money issuers including MNOs need to register themselves as payment banks with the Reserve Bank of India. These MNOs which offer mobile money services obtain a type of banking license which allows them to accept deposits, issue ATM/debit cards, and offer other financial services except lending (Reserve Bank of India, 2014).

The payment banks are required to invest a minimum 75 percent of their "demand deposit balances" in government securities/treasury bills with maturity up to one year and hold a maximum 25 percent in current and time/fixed deposits with other scheduled commercial banks ${ }^{12}$ for operational and liquidity management purposes.

\section{Figure 5. MNO-Led Mobile Money Services Dominate in Most Regions}

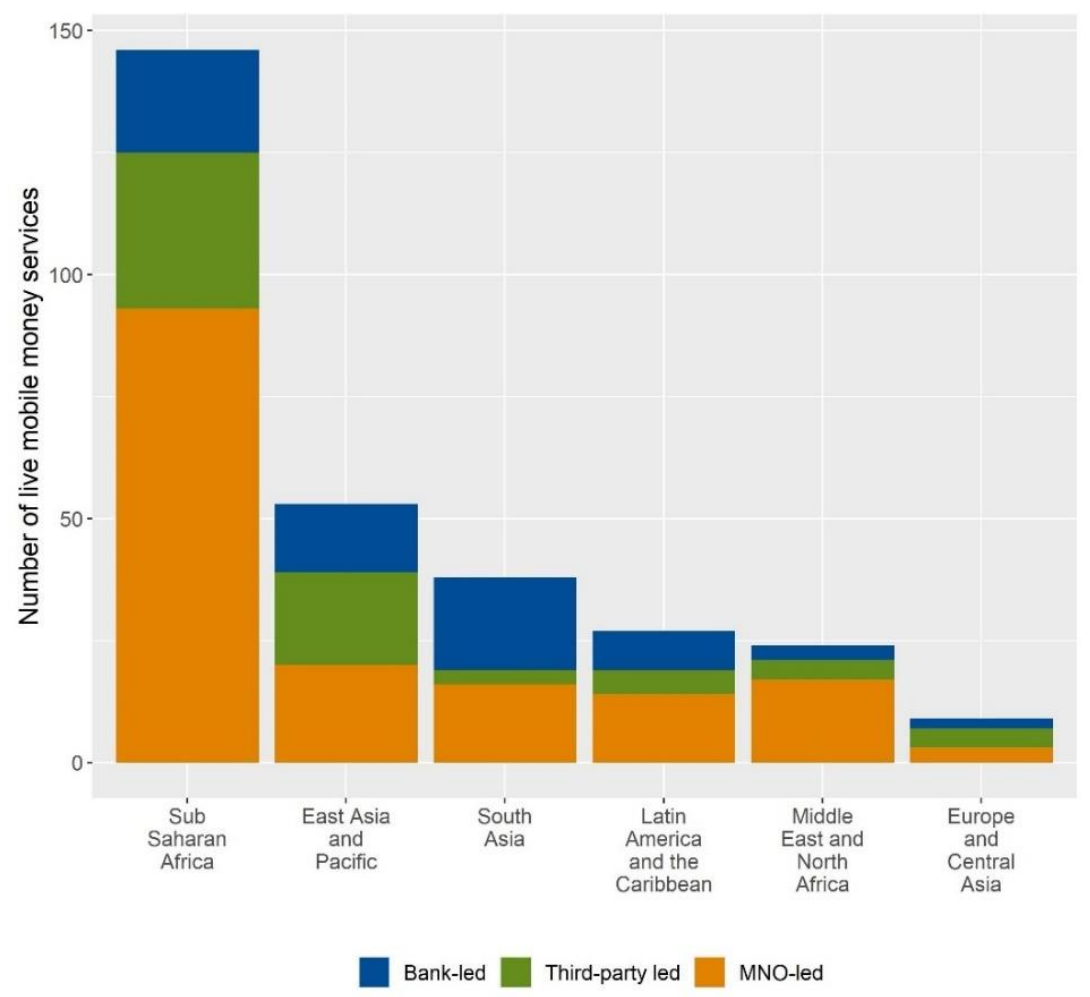

Source: IMF staff calculations and GSMA mobile money deployment tracker.

\footnotetext{
${ }^{12}$ A bank listed in the second schedule of the Reserve Bank of India (RBI) Act, 1934 is considered a scheduled bank. Scheduled banks are required to follow guidelines formulated by the RBI and maintain reserves with the RBI. Scheduled banks are eligible for loans from the RBI at bank rate and are given membership to clearing houses.
} 


\section{B. Regulations to Safeguard Mobile Money Customer Funds}

Mobile money regulations typically cover areas such as licensing, AML/CFT, and customer protection (Pelletier et al., 2019). This subsection focuses on mobile money regulations related to customer protection-specifically those put in place to safeguard customer funds stored in the mobile money system. Depending on the mobile money model in question, different regulations apply, and these regulations have direct implications for the treatment of mobile money in monetary statistics.

One of the most significant risks associated with mobile money usage, especially from the perspective of mobile money users, is loss of customer funds, which can arise due to insufficient liquidity or insolvency of the mobile money service provider. This concern is more pronounced for MNO-led mobile money services as these are operated by non-banks, which lie outside the scope of banking regulations.

To mitigate these risks, countries have introduced mobile money specific regulations over time, but it has been an evolving process. In 2007, when Safaricom began operating M-Pesa in Kenya, there was no law or regulation in the country for mobile money service providers. At the time, they started operating on the basis of a letter agreement with the Central Bank of Kenya. It was only in 2014 when, with the adoption of the National Payment Systems (NPS) Regulations, a formal legal framework for mobile money was put in place in the country. The NPS regulations have implemented several regulatory practices, including the safeguarding of customer funds. Following this example, other countries also adopted similar regulations, such as the Bank of Tanzania's e-Money Regulations in 2015 and the Bank of Ghana's Guidelines for e-Money Issuers in 2015 (Greenacre, 2018). All countries now mandate all mobile money service providers to keep 100 percent of their mobile money liabilities in liquid assets (GSMA, 2020b). Details are as follows:

\section{MNO-led model}

To date, the most common form of regulations for the MNO-led mobile money services is requiring MNOs to hold their mobile money liabilities as deposits at regulated financial institutions. However, some countries also use a combination of frameworks including allowing MNOs to invest in low risk securities. Depending on the jurisdiction, MNOs have different regulatory options on maintaining the liquid assets:

- Holding customer funds with banks: The most common approach is to require MNOs to deposit their entire outstanding mobile money liabilities in one or more banks or other regulated deposit taking institutions. Depending on a country's legal system, this type of account may be called a trust, escrow, fiduciary or custodial account (Kerse and Staschen, 2018). In Eswatini for instance, an MNO needs to ensure that balances in the trust account should always be equal to the total outstanding mobile money liabilities (Central Bank of Eswatini, 2019). In Seychelles, MNOs need to split the liabilities into trust accounts with a 
minimum of two banks (Central Bank of Seychelles, 2014). Other countries which follow a similar approach include Kenya, Ghana, Paraguay and Uganda. ${ }^{13}$

- Depositing customer funds with the central bank: Though not a common approach, some regulators require that MNOs hold at least a portion of their outstanding mobile money liabilities in the central bank while holding the rest in other regulated financial institutions like commercial banks. In a few limited cases, the regulations may even require the MNOs to hold their entire mobile money issuance as deposits with the central bank. The risk of loss of funds is minimal with the central bank being the lender of last resort. For example, Article 10 of El Salvador's Financial Inclusion Bill requires that mobile money service providers store customer funds in the central bank (Asamblea Legislativa de El Salvador, 2015).

- Investing funds in other liquid assets: Some countries give the option to MNOs to either maintain funds at regulated financial institutions or invest the customer funds in low-risk securities, such as government securities. This is the case for the West African Economic and Monetary Union (WAEMU), where customer funds can be invested in bank deposits but also in securities issued by central governments, regional financial institutions, and companies listed on the West African Regional Securities Exchange (BCEAO, 2015). In Malaysia, funds may be invested in high quality liquid assets in the form of deposits placed with licensed institutions or debt securities issued or guaranteed by the Federal Government and the Central Bank (Bank Negara Malaysia, 2003). In the Philippines, customer funds may be invested in bank deposits, government securities or other permitted liquid assets (Bangko Sentral ng Pilipinas, 2009). Similarly, in Bolivia, outstanding mobile money liabilities must be held in either cash by MNOs or invested in securities issued by the Bolivian Government and Central Bank or other permitted assets by the Central Bank (Autoridad de Supervisión del Sistema Financiero de Bolivia, 2018) (see Table 3).

\begin{tabular}{|c|c|c|c|c|}
\hline Country & Regulation & Year & Regulatory Requirement & Source \\
\hline Bolivia & $\begin{array}{l}\text { "Modificaciones al } \\
\text { reglamento para empresas } \\
\text { de pago móvil, al reglamento } \\
\text { de fidecoismo, y al manual } \\
\text { de cuentas para entidades } \\
\text { financieras, Circular ASFI } \\
548 . "\end{array}$ & 2018 & $\begin{array}{l}\text { Outstanding mobile money } \\
\text { liabilities must be held in } \\
\text { either cash by MNOs or } \\
\text { invested in securities issued } \\
\text { by the Bolivian Government } \\
\text { and Central Bank, or other } \\
\text { permitted assets by the } \\
\text { Central Bank. }\end{array}$ & $\begin{array}{l}\frac{\text { Autoridad }}{\text { de }} \\
\frac{\text { Supervisión }}{\text { del Sistema }} \\
\text { Financiero } \\
\text { de Bolivia } \\
\text { (page 26, } \\
\text { article 8) }\end{array}$ \\
\hline Malaysia & $\begin{array}{l}\text { "Guideline on Electronic } \\
\text { Money (E-Money), Act 627." }\end{array}$ & 2003 & $\begin{array}{l}\text { Funds may be invested in } \\
\text { high quality liquid assets in } \\
\text { the form of deposits placed } \\
\text { with licensed institutions or } \\
\text { debt securities issued or } \\
\text { guaranteed by the Federal } \\
\text { Government and the Central }\end{array}$ & $\begin{array}{l}\frac{\text { Bank }}{\text { Negara }} \\
\text { Malaysia } \\
\text { (page 10, } \\
\text { section C) }\end{array}$ \\
\hline
\end{tabular}

${ }^{13}$ Central Bank of Kenya E-money Regulations 2013, Ghana e-Money Guidelines, Art. 16, Resolución No. 6 de 2014 - Reglamento de Medios de Pagos Electrónicos, Art. 15, Uganda e-Money Guidelines, Art. 16. 


\begin{tabular}{|c|c|c|c|c|}
\hline & & & $\begin{array}{l}\text { Bank. Also, other instruments } \\
\text { as may be specified by the } \\
\text { Bank. }\end{array}$ & \\
\hline Philippines & $\begin{array}{l}\text { "Guidelines governing the } \\
\text { Issuance of Electronic } \\
\text { Money (e-money) and the } \\
\text { Operations of Electronic } \\
\text { Money Issuers (EMI), } \\
\text { Circular No. 649." }\end{array}$ & 2009 & $\begin{array}{l}\text { Customer funds may be } \\
\text { invested in bank deposits, } \\
\text { government securities or } \\
\text { other permitted liquid assets. }\end{array}$ & $\begin{array}{l}\frac{\text { Bangko }}{\text { Sentral ng }} \\
\frac{\text { Pilipinas }}{\text { (page 4, }} \\
\text { section D) }\end{array}$ \\
\hline WAEMU & $\begin{array}{l}\text { “Instruction } \mathrm{N}^{\circ} 008-05-2015 \\
\text { regissant les Conditions et } \\
\text { Modalités d'Exercise des } \\
\text { Activités des Emetteurs de } \\
\text { Monaie Électronique dans } \\
\text { les États Membres de } \\
\text { l'Union Monetaire Ouest } \\
\text { Africaine (UMOA)." }\end{array}$ & 2015 & $\begin{array}{l}\text { Customer funds can be } \\
\text { invested in bank deposits but } \\
\text { also in securities issued by } \\
\text { central governments, regional } \\
\text { financial institutions, and } \\
\text { companies listed on the West } \\
\text { African Regional Securities } \\
\text { Exchange. }\end{array}$ & $\frac{\text { BCEAO }}{(\text { page } 30)}$ \\
\hline
\end{tabular}

\section{Bank-led model}

Mobile money issued by banks may be classified in their books either as deposit liabilities or as a distinct mobile money liability within deposit liabilities. Mobile money customer funds are typically pooled in a single account rather than individual accounts (Grossman, 2016). These funds are monitored under the overall prudential supervision of the bank (Izaguirre et al., 2019).

The next section examines how these mobile money business model types and regulations affect the treatment of mobile money in monetary statistics and the calculation of monetary aggregates.

\section{Mobile Money ANd Monetary Aggregates}

Methodological questions pertaining to the compilation of monetary statistics are best discussed in the context of the IMF's 2016 Monetary and Financial Statistics Manual and Compilation Guide (MFSMCG) which offers guidance for the compilation of monetary statistics to promote the production of cross-country comparable monetary data on the central bank, other depository corporations (ODCs), and other financial corporations (OFCs) (see Box 3).

\section{Box 3. Institutional Units and Sectors in Macroeconomic Statistics}

For macroeconomic statistics purposes, all corporations-namely, institutional units that produce goods and services for the market, are legally separated from their owners, and are legally liable for their actions-are divided into financial corporations and nonfinancial corporations. The 2008 System of National Accounts (SNA) divides the Financial Corporations sector into nine subsectors: (1) central bank, (2) deposit taking corporations except the central bank, (3) money market funds (MMFs), (4) non-MMF investment funds, (5) other financial intermediaries except insurance corporations and pension funds, (6) financial auxiliaries, (7) captive financial institutions and money lenders, (8) insurance corporations, and (9) pension funds.

For monetary statistics, the MFSMCG combines SNA subsectors (2) deposit taking corporations except central bank and (3) MMFs into one subsector called Other Depository Corporations 
(ODCs). All other sub-sectors except the central bank and the deposit taking corporations are collectively known as the Other Financial Corporations (OFCs)

Financial corporations (FCs), for monetary and financial statistics purposes consist of the central bank, ODCs and OFCs:

- ODCs are all financial corporations that issue liabilities or in other words accept deposits included in broad money. In most countries, commercial banks are the bulk of ODCs, but other institutions that issue monetary liabilities such as credit unions, savings banks, microfinance institutions and money market funds may also be included in ODCs.

- Depository Corporations (DCs) consist of the central bank and ODCs.

- OFCs include insurance corporations, pension funds, non-money market investment funds, and other financial intermediaries which incur liabilities that are excluded from broad money.

Non-financial corporations are corporations or quasi corporations whose principal activity is production of goods and nonfinancial services.

DCs are the only money issuers in most countries - thus the balance sheet data of central bank and ODCs sectoral balance sheets are especially important from the perspective of broad money calculation. DCs are thus considered as broad money issuers. On the other hand, OFCs, NFCs, households and governments are considered as broad money holders.

Source: MFSMCG.

More than 170 countries and territories follow the recommendations of the MFSMCG in compiling monetary and financial statistics and report them to the IMF using the standardized report forms (SRFs), a reporting framework prescribed in the MFSMCG. Specifically, the balance sheet information related to the central bank is reported in the SRF-1SR form, the aggregated balance sheet of the banking system or ODCs in the SRF-2SR form and the aggregated balance sheet of non-banks or the OFCs in the SRF-4SR (Box 4). Information in the SRFs are then used to compile and disseminate key monetary aggregates including monetary base and broad money (see Annex III). These data are reported to the IMF and disseminated as the monetary and financial statistics (MFS) through the MFS database (Annex IV).

\section{Box 4: Standardized Report Forms (SRFs): 1SR, 2SR, 4SR, and 5SR}

The MFSMCG prescribes standardized report forms (SRFs) to report monetary data to the IMF, thus providing countries with a tool to compile and report harmonized data for the central bank, ODCs, and OFCs. There are three SRFs corresponding to the three sub-sectors of the financial corporations sectors:

- SRF-1SR: sectoral balance sheet of the central bank

- SRF-2SR: sectoral balance sheet of ODCs

- SRF-4SR: sectoral balance sheet OFCs 
These SRFs use a harmonized accounting presentation of assets and liabilities (stocks only) of the FCs with primary breakdowns by financial instrument (presented in order of their relative liquidity, including nonfinancial assets), then disaggregated by currency of denomination (domestic and foreign), and finally by counterpart sector (corresponding to the main sectors of the 2008 SNA).

Based on the SRFs, analytical surveys or presentations are prepared by reorganizing the sectoral balance sheet data to present the intermediation role of the relevant sector-the two important analytical surveys for monetary policy purposes are the central bank survey (CBS) and the depository corporations survey (DCS) (see Annex III).

In the CBS, the liability side is structured to show the components of monetary base and the asset side focusses on the financing extended to the non-residents and the various domestic sectors.

Similarly, in the DCS the liability side shows the components of broad money and the asset side shows the DC's claims on non-residents and the domestic sectors, thus providing a link between broad money supply and the net foreign assets and net domestic assets.

In addition to the SRFs-1SR, 2SR and 4SR, the SRF-5SR, based on the DCS, contains additional line items for components of broad money by institutional units other than FCs. In SRF-5SR, the data reporting is not standardized across countries, but the MFSMCG provides guidance on determining financial instruments to be included in money aggregates in accordance with the structure and other features of the financial system. These include currency in circulation issued by the central government, holdings of foreign currency that is widely accepted as a medium of exchange in domestic sectors, and electronic deposits issued by other nonfinancial corporations.

This section examines the statistical treatment of mobile money in computing monetary statistics and how mobile money impacts the measurement of money based on the MFSMCG framework and the data collected in the SRFs.

\section{A. Treatment of Mobile Money in Monetary Statistics}

According to the MFSMCG, money has the following properties: a medium of exchange, unit of account and store of value. ${ }^{14}$ The most common and widely used measure of money aggregates is "broad money." The MFSMCG describes broad money as the sum of all liquid financial instruments held by households, businesses etc. that are widely accepted in an economy as a medium of exchange, and/or that can be converted into a medium of exchange at short notice at, or close to, their full nominal value. Currency in circulation and transferable deposits $^{15}$ - the most liquid financial instruments - meet the definition of broad money. Nontransferable deposits such as savings deposits, sight deposits, and fixed deposits of shortterm maturity are also included in broad money as they are redeemable at full value upon

\footnotetext{
${ }^{14}$ See MFSMCG 6.8-6.10.

${ }^{15}$ Transferable deposits comprise all deposits that are (1) exchangeable for banknotes and coins on demand at par and without penalty or restriction; and (2) directly usable for making payments to third parties by check, draft etc. (MFSMCG 4.30). Non-transferable deposits comprise all claims, other than transferable deposits, that are represented by evidence of deposit including fixed-term deposits, sight deposits, etc. (MFSMCG 4.43).
} 
request without penalty and fee and satisfy the features of moneyness, i.e., high degrees of liquidity and stability as a store of nominal value. ${ }^{16,17}$ Put another way, broad money consists of the liquid liabilities of the central bank and the banking system (collectively known as the Depository Corporations (DCs) sector in the MFSMCG-see Box 3) to the rest of the domestic economy, except the central government.

A key question in this paper is whether mobile money is part of broad money according to the MFSMCG. The treatment of mobile money in monetary statistics is addressed under the broad category of electronic money (e-money). E-money is defined as a payment instrument whereby monetary value is electronically stored on a physical device or remotely at a server which represents a claim on the issuer (MFSMCG 4.38). Examples of e-money include prepaid cards, mobile wallets or web-based e-money (such as PayPal, if monetary value is electronically stored), and mobile money (IMF, 2018; MFSMCG; Kireyev, 2017). ${ }^{18}$

In the MFSMCG, e-money is classified as deposits rather than currency. ${ }^{19}$ As e-money including mobile money can be used for direct payments to third parties, it qualifies as a transferable deposit. Since transferrable deposits are typically included in broad money, mobile money is included in broad money according to the MFSMCG.

\section{B. Compilation of Mobile Money Data for Monetary Statistics}

While the guidance is clear that mobile money liabilities are to be treated as transferrable deposits and included in broad money, this may not directly translate into how mobile money data are collected for the purposes of monetary statistics in practice. The treatment of mobile money in monetary data compilation varies depending on the mobile money business model and/or the regulatory framework adopted in the country. This subsection elaborates these details.

\section{MNO-led Model}

The MNO-led model of mobile money consists of MNOs or entities that partner with MNOs to offer mobile money services. As noted earlier, all countries around the world where mobile money services exist currently have regulations which require MNOs to keep 100 percent of their mobile money liabilities in liquid assets-which in most cases are in the form of deposits at

\footnotetext{
16 See MFSMCG 6.12 .

17 Money-market fund (MMF) shares held by the money-holding sectors and some short-term debt securities may also be included in broad money (MFSMCG 6.47-6.48).
}

18 Many digital instruments or services used for payments do not qualify as e-money. Bitcoins are not e-money (they are classified as nonfinancial assets-see IMF, 2018), and neither are credit and debit cards, as no monetary value is stored on them. Store cards are also not e-money as their use is limited to only the issuing stores.

\footnotetext{
${ }^{19}$ According to MFSMSG, currency consists of notes and coins that are of fixed nominal values and are issued or authorized by central banks or governments while deposits are nonnegotiable contracts that represent the placement of funds available for later withdrawals (MFSMCG 4.25 and 4.29). E-money falls under deposits and specifically under transferrable deposits.
} 
the central bank and other regulated financial institutions and in limited cases, in the form of investments in sovereign securities or other permitted assets ${ }^{20}$ (GSMA, 2020b). The MFS treatment of mobile money in each of these cases is discussed below.

\section{Case 1: Mobile money liabilities of MNOs held as deposits at a regulated financial institution}

In countries where MNOs are required to keep their mobile money liabilities in the form of deposits at regulated deposit-taking financial institutions like banks, accounting for mobile money in monetary statistics may be relatively straightforward. Since the MNOs by law are required to maintain deposits with banks equivalent to the amount of mobile money issuance, the data on outstanding mobile money balances in the country are reflected on the balance sheet of banks (or ODCs using the MFSMCG terminology). These deposits by design are highly liquid so that the MNOs can make available these funds to the mobile money account holders on demand. Thus, these are recorded under transferrable deposits on the bank's balance sheet.

In terms of MFS data collected by the IMF, the aggregated balance sheet of the banking system including all assets and liabilities organized by instruments are reported in the SRF-2SR. Since all the liquid liabilities of the banks need to be included in the calculation of broad money in the country, the transferrable deposits of MNOs at the banks-which are equivalent to the value of their mobile money issuance-are also accounted for in broad money.

In a few countries where MNOs are required to deposit customer funds at the central bank, equal to the total amount of mobile-money liabilities, the process of accounting for mobile money in the calculation of broad money is quite similar. The demand deposits of MNOs at the central bank reflecting their mobile money customer funds become part of the liabilities of the central bank balance sheet. In the MFS, the balance sheet of the central bank is reported to the IMF in the SRF-1SR. Given the MNO's demand deposits at the central bank are highly liquid and transferable, they are also included in the calculation of broad money.

In countries where MNOs are given the option to keep their mobile money customer funds received from customers either at the central bank or at the ODCs, the treatment is no different. These deposits are reflected in part in the central bank liabilities and in part in the banking system liabilities which ultimately feeds into the calculation of broad money. Care must be taken by compilers to avoid duplication-i.e., the mobile money liabilities of MNOs are not separately added in broad money calculation as they have already been accounted for.

The challenge, however, arises when the deposits maintained by the MNOs in the central bank or at the banks are restricted in nature-i.e., the deposits that cannot be accessed by the depositor (MNOs) until the appropriate conditions and obligations have been fulfilled, for example the escrow account can be used by the MNOs only to meet mobile money customer demand. ${ }^{21}$ In those cases, these deposits are considered as "restricted deposits" (a type of

\footnotetext{
${ }^{20}$ Depending on the jurisdiction, other permitted assets may include debt securities guaranteed by the federal government or central bank or issued by regional financial institutions.

${ }^{21}$ Note that MNOs are usually required to segregate customer funds and keep them in trust or custodial accounts to safeguard them and prevent comingling with the companies' funds. The restrictions, if any, are to the customer funds only and not to the other deposits made by the MNOs at the banks.
} 
nontransferable deposits in the MFSMCG) and excluded from the calculation of broad money. In other words, the amount of mobile money liabilities in the country will not be included in broad money automatically. In these cases, compilers need to ensure that mobile money liabilities of these MNOs are covered for the purposes of MFS compilation separately so that they can be included in the computation of broad money. How this can be done is discussed in detail in Box 5.

In many countries, MNOs earn interest on their deposits (corresponding to the customer balances) kept with commercial banks. There has been an ongoing debate of whether MNOs should pass on the interest to the customers or not. The practice has varied country to country depending on the regulations (Suri et al., 2021). The MNO in Tanzania, Tigo Pesa was the first to pass on the interest to the customers (McKay, 2016). Bank of Ghana also required the MNOs to pass on at least 80 percent of their interest earned to the customers (Bank of Ghana, 2015). In Kenya, interest on MNOs' trust accounts are applied to corporate social responsibility (CSR) activities (Ahmad et al., 2020).

Irrespective, the statistical treatment of mobile money in MFS does not change. The MFSMCG requires that the accrued interest should be included in the outstanding amounts of the underlying financial assets or liabilities. In other words, given that the deposits of MNOs with banks (equivalent to customer funds) are in the banking system and recorded in monetary statistics, the interest amounts are also already included.

\section{Case 2: Mobile money liabilities of MNOs invested in sovereign securities or other permitted} assets

In a few select cases such as Malaysia, Philippines, Bolivia or the WAEMU member countries, MNOs have the additional option of investing in sovereign securities or other permitted assets in order to fulfil the requirement of maintaining 100 percent of their mobile-money liabilities in liquid assets (see Table 3 ). In such cases, the process of accounting for mobile money in compilation of broad money is more involved. While the proportion of mobile money liabilities of MNOs maintained as deposits at banks or at the central bank are already included in monetary data reported to the IMF (in the balance sheet data of the banks and central bank), the proportion invested in securities are not. In such cases, where the regulations are layered, compilers may consider collecting balance sheet information of the MNOs and including them in the aggregated balance sheet of the ODCs (see Box 5 for details).

Furthermore, in case the regulations requiring MNOs to maintain their mobile money liabilities in liquid assets are not fully implemented or enforced, these countries are encouraged to collect data from MNOs to be included in the broad money calculation as detailed in Box 5. In other words, compilers of monetary statistics will need to review the prevailing situation in the country and decide how mobile money are to be accounted for in compilation of monetary statistics and make necessary adjustments in the calculation of broad money with additional information which may be separately collected from MNOs. 


\section{Box 5. Additional Treatments of Mobile Money in MFS Reporting}

In some countries, the regulatory framework may be such that mobile money liabilities of MNOs are not reflected in the ODC balance sheet or the central bank balance sheet. In those cases, compilers need to take additional steps to account for the mobile money liabilities in the country by collecting balance sheet data from the MNOs directly. There are two ways to account for this information in the monetary data reported in SRFs.

\section{Assess if MNOs can be considered ODCs for MFS and include their balance sheet in the sectoral balance sheet (SRF-2SR)}

MNOs are usually telecom companies in the business of offering telecom and internet services which for the purposes of macroeconomic statistics are classified in the non-financial corporations' sectors. For monetary statistics, however, this may not always be the case. The sectoring of institutional units is based on the economic objectives, functions, and behavior. More generally, the key to classifying a unit in macroeconomic statistics is not its legal status but rather the economic nature of the entity. ${ }^{22}$

The MFSMCG indeed suggests that electronic money institution should be classified as an ODC when they are in the business of financial intermediation and accept deposits which are included in broad money (Para 3.137 MFSMCG). MNOs which offer mobile money services thus can be treated as ODCs for MFS purposes and their balance sheet included in the sectoral balance sheets for ODCs.

Most jurisdictions require the mobile money issuers to be established as a separate legal entity from the MNO. Their balance sheet which consist of their mobile money activities alone must be included while compiling the SRF-2SR.

If the MNOs do not organize the business of mobile money as a separate unit but one of the activities is issuing e-money amongst other things, then their treatment as ODCs for monetary statistical purposes depends on whether their mobile money business can be treated as a quasicorporation. A "quasi-corporation" in the MFSMCG terminology is defined as an unincorporated enterprise that functions in almost all respects as if it were incorporated. For purposes of sectoring, they are treated as institutional units (corporations) separate from the units that own them. In practice, for a quasi-corporation to exists, it must have a complete set of accounts including a balance sheet of assets and liabilities or can produce such a set of accounts as needed; its assets and liabilities must be separate from its owners; and are self-contained and independent. If the mobile money business of the MNO can be considered a quasi-corporation for statistical purposes, then it is to be classified as part of the ODCs.

In sum, when an MNO is classified as ODC, then balance sheet are included in the aggregated balance sheet for the ODC sector (SRF-2SR) like in the case of commercial banks and credit unions, etc. The customer funds are then treated as transferrable deposits which will ultimately feed into the calculation of broad money.

${ }^{22}$ MFSMCG 3.13. 
Report mobile money as additional components of broad money (SRF-5SR):

While the MFSMCG provides some discussion on the characteristics of the financial instruments that should be included as part of broad money, the definition is only intended to help monetary statistics compilers determine the scope of broad money, taking into account the structure and other features of the financial system in their own economies. Thus, in the SRFs, there is an additional report form (SRF-5SR) which provides the option to countries to include components of broad money that are not captured in the report forms for the central bank (SRF-1SR), the other depository corporations (SRF-2SR), and the other financial corporation (SRF-4SR) (see Box 4).

The SRF-5SR form has the option of including deposits of nonfinancial corporations like MNOs in the broad money calculation. Therefore, in countries where MNO deposits at the central bank or at banks are restricted in nature and are not captured by a default broad money calculation, the mobile money customer funds with MNOs may be included in the 5 SR form to be reflected as part of broad money.

Note that these additional data collection methods are needed only when mobile money liabilities are not counted in the banking system.

\section{Bank-led Model}

In the MFS, the treatment of bank-led models of mobile money is much simpler. As discussed above, in a typical bank-led model, the practice is for banks to pool and store funds from its mobile money customers in a single account rather than opening an individual deposit account for each customer (Grossman, 2016).

For such bank-led mobile money service providers, as long as the mobile money customer balances are accounted for in the banks' books either as customer deposits or e-money accounts, these are classified as transferrable deposits with the banks which will ultimately feed into the calculation of broad money under the framework of the MFSMCG.

In sum, mobile money appears to be largely captured in the calculation of broad money in most countries that have adopted the MFSMCG guidance (Figure 6). This is mainly because most jurisdictions around the world have regulations that require the issuers to mirror the value of the outstanding mobile money in an account at a regulated financial institution or at the central bank. This means that mobile money balances are already being accounted in the existing monetary and financial statistics data reported in the SRFs to the IMF (IMF, 2018). 


\begin{tabular}{|c|c|c|c|c|}
\hline \multicolumn{5}{|c|}{ Figure 6. Treatment of Mobile Money in MFS } \\
\hline & A: Regulation & $\begin{array}{c}\text { B: Impact of the regulation } \\
\text { on data }\end{array}$ & $\begin{array}{l}\text { C: Additional treatments } \\
\text { needed? }\end{array}$ & $\begin{array}{l}\text { D: How will mobile money } \\
\text { liabilities be reflected in } \\
\text { broad money calculation? }\end{array}$ \\
\hline \multirow{3}{*}{$\begin{array}{l}\text { MNO-led } \\
\text { model }\end{array}$} & $\begin{array}{l}\text { Mobile money liabilities of } \\
\text { MNOs held as deposits at a } \\
\text { central bank or commercial } \\
\text { banks. }\end{array}$ & $\begin{array}{l}\text { Data collected from the } \\
\text { central bank and commercials } \\
\text { banks on the amount of } \\
\text { transferrable deposits include } \\
\text { data on mobile money } \\
\text { liabilities of MNOs. }\end{array}$ & $\begin{array}{l}\text { No separate data collection } \\
\text { needed for mobile money } \\
\text { liabilities. }\end{array}$ & $\begin{array}{l}\text { Transferrable deposits with } \\
\text { the central bank and } \\
\text { commercial banks are part of } \\
\text { broad money calculation. }\end{array}$ \\
\hline & $\begin{array}{l}\text { Mobile money liabilities of } \\
\text { MNOs held as bank deposits } \\
\text { or invested in sovereign } \\
\text { securities or other permitted } \\
\text { assets. }\end{array}$ & \multirow{2}{*}{$\begin{array}{l}\text { Data collected from the } \\
\text { central bank and commercial } \\
\text { banks on the amount of } \\
\text { transferrable deposits may } \\
\text { not reflect the mobile money } \\
\text { liabilities. }\end{array}$} & \multirow{2}{*}{$\begin{array}{l}\text { Assess if MNOs can be } \\
\text { considered ODCs and include } \\
\text { MNOs in the balance sheet of } \\
\text { the ODC sector. Mobile } \\
\text { money liabilities will be } \\
\text { considered transferrable } \\
\text { deposits. } \\
\text { OR } \\
\text { Collect data on mobile money } \\
\text { liabilities of MNOs directly } \\
\text { and include in the monetary } \\
\text { aggregates (SRF 5SR). }\end{array}$} & $\begin{array}{l}\text { Liquid liabilities of the ODCs } \\
\text { are part of broad money } \\
\text { calculation. }\end{array}$ \\
\hline & $\begin{array}{l}\text { Regulations not yet } \\
\text { implemented. }\end{array}$ & & & $\begin{array}{l}\text { The SRF-5SR provides the } \\
\text { options to include } \\
\text { components of broad money } \\
\text { that are not captured in the } \\
\text { SRFs for central bank, ODCs } \\
\text { and OFCs. }\end{array}$ \\
\hline $\begin{array}{c}\text { Bank-led } \\
\text { model }\end{array}$ & $\begin{array}{l}\text { Mobile money liabilities held } \\
\text { as deposits at a bank by } \\
\text { definition and subject to } \\
\text { prudential regulations. }\end{array}$ & $\begin{array}{l}\text { Data collected from } \\
\text { commercials banks on the } \\
\text { amount of transferrable } \\
\text { deposits include data on } \\
\text { mobile money liabilities of } \\
\text { MNOs. }\end{array}$ & $\begin{array}{l}\text { No separate data collection } \\
\text { needed for mobile money } \\
\text { liabilities. }\end{array}$ & $\begin{array}{l}\text { Transferrable deposits } \\
\text { commercial banks are part of } \\
\text { broad money calculation. }\end{array}$ \\
\hline
\end{tabular}

CInternational Monetary Fund. Not for Redistribution 


\section{The impact of mobile money on broad money composition}

More generally, mobile money has the potential to change the composition of broad money without impacting its size or volume. As mobile money is increasingly used, currency in circulation will likely decrease while deposits with the banking system will increase since mobile money balances outstanding with the mobile money service providers will in most cases be accounted for in monetary statistics as part of transferrable deposits with the banks.

Kipkemboi and Bahia (2019) have studied whether mobile money has led to a decline to the use of cash, by examining the trend of the ratio of the currency outside the banking sector to broad money in select countries of Kenya, Uganda, Ghana and Rwanda. They find a negative growth of the ratio, suggesting that the use of cash has declined while bank deposits have increased. ${ }^{23}$

However, mobile money balances are still small relative to the size of transferable deposits and currency in most countries to see this trend prominently across countries. For example, the outstanding amount of mobile money balance is a mere fraction of that of deposits at commercial banks (Figure 7).

While mobile money is only a small part of broad money currently, as mobile money gains more popularity, its impact on calculation of monetary aggregates may become more pronounced. It is thus crucial that statistical compilers ensure that mobile money is being accounted for in the calculation of monetary aggregates. In this regard, there may be some merit in distinguishing between deposits of customer funds (from mobile money) in banks and other types of bank deposits included in broad money in the future. More generally, given mobile money has implications for various policy aspects ranging from its impact on financial inclusion to monetary aggregates, it is important to continue to monitor mobile money trends and developments.

\footnotetext{
${ }^{23}$ More broadly, the cash component of broad money ("cash in circulation") is often used as an indicator to track cash usage in an economy. Given the growing interest in digital money including central bank digital currencies (CBDCs), understanding the costs and drivers of demand for cash is becoming important (see for example, Khiaonarong and Humphrey, 2019). Comprehensive data on broad money components such as cash usage and e-payments are key in this regard (Bech et al., 2018).
} 


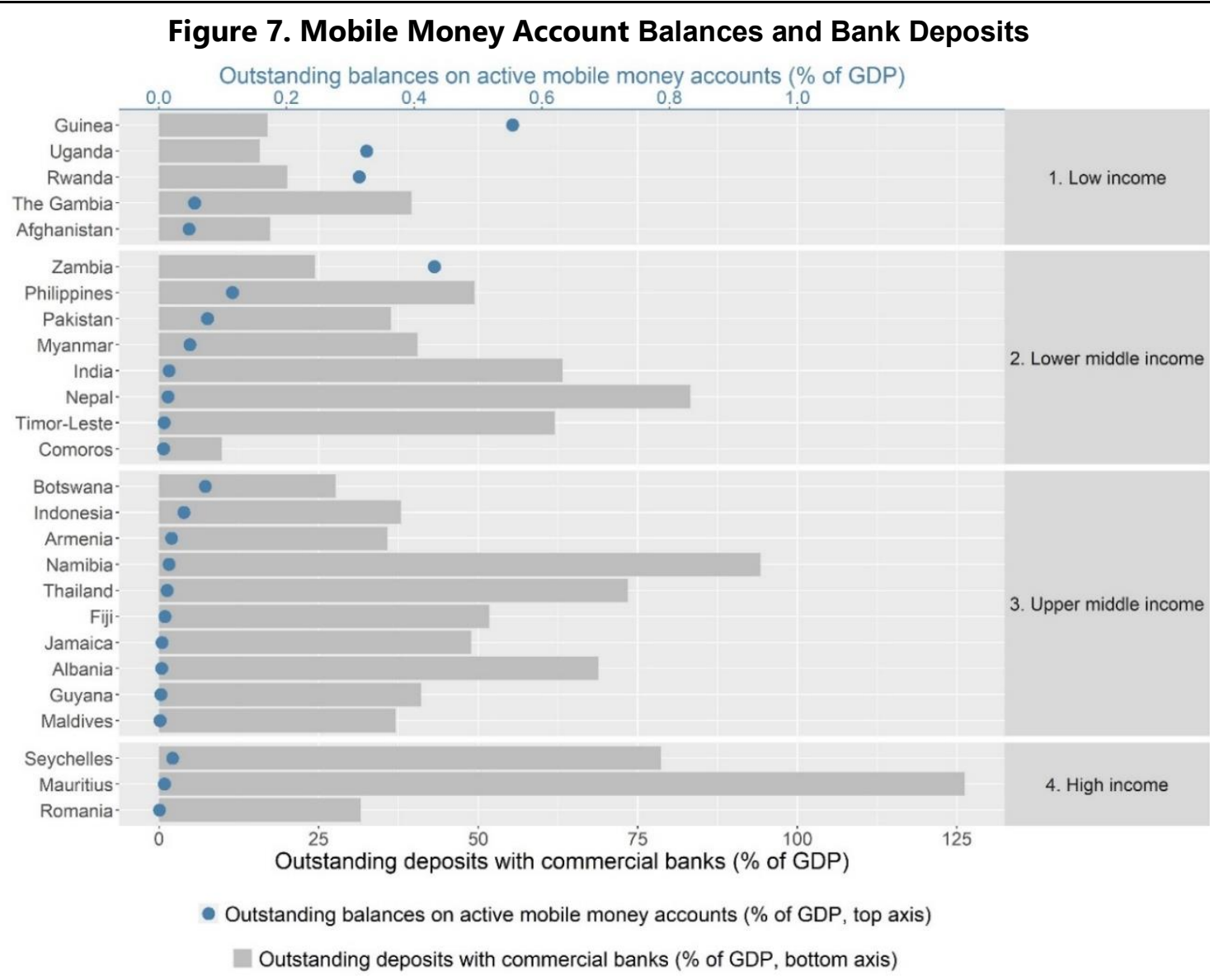

Source: IMF staff calculations and IMF Financial Access Survey.

Note: This figure presents the outstanding deposits with commercial banks (gray bars on the bottom xaxis) and outstanding balance on active mobile money accounts (blue dots on the top x-axis) as percentage of GDP in 2019 or the latest year available for select countries.

\section{CONCLUSION}

This paper analyzed recent developments of mobile money from a statistical perspective, examining measurement and data collection issues. Specifically, the paper reviewed stylized facts about mobile money using avaiable data and also clarified the treatment of mobile money in monetary statistics drawing on the methodological framework provided by the MFSMCG.

The FAS data provide useful insights into how mobile money has helped unbanked or underbanked populations to gain access to financial services in many developing economies. The data show that mobile money is a much more accessible means of using basic financial services than traditional banking as there are more mobile money agents than ATMs and bank branches combined in these economies. This increased access can be also seen in the number of mobile money accounts-there are more registered mobile money accounts than traditional bank accounts in many low- and middle-income economies. A similar trend also holds in the usage of mobile money, as evidenced by the increased transaction values and volumes. 
Mobile money service providers have recently started to expand their suite of financial services for customers, including savings and loans products via mobile money accounts. However, relatively little is known about the degree of the usage of such services. The analysis based on transaction level data from Kenya confirms that mobile money customers are indeed starting to use new financial services, with about half of the mobile money accounts in the study being used for such transactions. These findings also point to the importance of proper measurement of mobile money activity, especially for the central bank policymaking, as mobile money continues to expand into other streams like credit.

On measurement issues related to mobile money, the paper clarified the treatment of mobile money in monetary statistics and its implications for calculation of monetary aggregates to address the question of whether mobile money is counted as part of broad money. Answering this question warrants an understanding of the mobile money value chain, the ensuing business models, and the regulations in place to safeguard customer funds. Mobile money business models can be either MNO-led or bank-led, depending on the type of the entity responsible for the issuance of mobile money. The type of business model then determines the regulations to be applied, which in turn have direct implications for the treatment of mobile money in monetary statistics.

The methodological guidance provided by the MFSMCG on the treatment of mobile money is relatively clear-cut-mobile money liabilities need to be included as part of broad money in monetary statistics. However, how mobile money affects the measurement of monetary aggregates depends on the mobile money business model and/or the regulatory framework. For an MNO-led model, mobile money is reflected in broad money as long as regulations require mobile money liabilities are secured in the form of deposits at a regulated financial institution, which is the case in many countries. If regulations allow mobile money liabilities to be invested in sovereign securities or other permitted assets, more involved steps may be needed, including collecting additional information from the MNO. For a bank-led model, since mobile money balances are already recorded as part of the bank balance sheet, they feed directly into the calculation of broad money.

While this paper focused on mobile money, there are other fintech products and services whose data needs and potential measurement issues are yet to be fully explored. These financial innovations include mobile payment applications known as mobile wallets and neobanks (online only banks), which offer internet-based financial services without physical presence. More recently, policymakers are also increasingly focusing on the potential digital form of money such as stablecoins and central bank digital currencies (CBDCs). ${ }^{24}$ These are important topics that require further research, and understanding the statistical treatment of these products in monetary statistics is fundamental in monitoring their developments as well as supporting policy analysis.

${ }^{24}$ See IMF (2019b) which briefly touches upon CBDCs. More work is under way on the statistical treatment of digital money including CBDCs. 


\section{REFERENCES}

Adrian, T. and T. Mancini-Griffoli. 2019. "The Rise of Digital Money". IMF Fintech Notes No 19/01, International Monetary Fund, Washington, DC.

Ahmad, A. H., C. Green and F. Jiang. 2020. "Mobile Money, Financial Inclusion and Development: A Review with Reference to African Experience." Journal of Economic Surveys 34 (4): 753-792.

Aron, J., J. Muellbauer and R. Sebudde. 2015. "Inflation forecasting Models for Uganda: is Mobile Money relevant?" Centre for Policy Research Discussion Paper Series 10739: 1-66, London.

Asamblea Legislativa de EI Salvador. 2015. "Reformas a la ley para facilitar la inclusión financiera, Decreto No. 464." San Salvador.

Autoridad de Supervisión del Sistema Financiero de Bolivia. 2018. "Modificaciones al reglamento para empresas de pago móvil, al reglamento de fidecoismo, y al manual de cuentas para entidades financieras, Circular ASFI 548." La Paz.

Bangko Sentral ng Pilipinas. 2009. "Guidelines governing the Issuance of Electronic Money (emoney) and the Operations of Electronic Money Issuers (EMI), Circular No. 649." Manila.

Bank of Ghana. 2015. "Guidelines for E - Money Issuers in Ghana.” Accra.

Bank Negara Malaysia. 2003. "Guideline on Electronic Money (E-Money), Act 627.” Kuala Lumpur.

Bazarbash, M., H. Carcel-Villanova, E. Chhabra, Y. Fan, N. Griffin, J. Moeller and K. Shirono. 2020. "Mobile Money in the COVID-19 Pandemic." IMF Special Series on COVID-19, International Monetary Fund, Washington, DC.

Bech M. L., U. Faruqui, F. Ougaard, and C. Picillo. 2018. "Payments are a-changin' but Cash still rules," BIS Quarterly Review (March).

BCEAO. 2015. "Instruction N008-05-2015 regissant les Conditions et Modalités d'Exercise des Activités des Emetteurs de Monaie Électronique dans les États Membres de l'Union Monetaire Ouest Africaine (UMOA)." Dakar.

Bill and Melinda Gates Foundation. 2015. "Assessing Risk in Digital Payments." Special Report, Financial Services for the Poor, Seattle.

Blumenstock, J. E., N. Eagle and M. Fafchamps. 2016. "Airtime Transfers and Mobile Communications: Evidence in the Aftermath of Natural Disasters." Journal of Development Economics 120: 157-181.

Central Bank of Eswatini. 2019. "Practice Note for Mobile Money Service Providers." Mbabane.

Central Bank of Seychelles. 2014. "Mobile payment services - Approval to commence Pilot Program." Victoria. 
Claessens, S., J. Frost, G. Turner and F. Zhu. 2018. "Fintech Credit Markets around the World: Size, Drivers and Policy Issues." BIS Quarterly Review (September).

Cornelli, G., J. Frost, L. Gambacorta, R. Rau, R. Wardrop and T. Ziegler. 2020. "Fintech and Big tech Credit: a new Database." BIS Working Papers No 887, Bank for International Settlements, Basel.

Dupas, P., D. Karlan, J. Robinson and D. Ubfal. 2018. "Banking the Unbanked? Evidence from Three Countries." American Economic Journal: Applied Economics 10 (2): 257-297.

Espinosa-Vega, M., K. Shirono, H. Carcel-Villanova, E. Chhabra, B. Das, and Y. Fan. 2020. "Measuring Financial Access: 10 Years of the IMF Financial Access Survey." IMF Departmental Paper No. 20/08, International Monetary Fund, Washington, DC.

Global System for Mobile Communications (GSMA). 2018. "Mobile Money Policy and Regulatory Handbook." London.

Global System for Mobile Communications (GSMA). 2020a. "State of the Industry Report on Mobile Money 2019." London.

Global System for Mobile Communications (GSMA). 2020b. "The Mobile Money Regulatory Index 2019." London.

Greenacre, J. 2018. "Regulating Mobile Money: a functional Approach." Pathways for Prosperity Commission Background Paper Series no. 4, Oxford.

Grossman, J. 2016. "Safeguarding Mobile Money: How Providers and Regulators can ensure that Customer Funds are protected." GSMA Report, Global System for Mobile Communications, London.

Hammer, C. L., D. C. Kostroch, G. Quirós, and STA Internal Group. 2017. "Big Data: Potential, Challenges, and Statistical Implications." IMF Staff Discussion Note 17/06, International Monetary Fund, Washington, DC.

International Monetary Fund (IMF). 2018. "Measuring Digital Economy." IMF Staff Report, Washington, DC.

International Monetary Fund (IMF). 2019a. “Mobile Money Note 2019.” Washington, DC.

International Monetary Fund (IMF). 2019b. "Treatment of Crypto Assets in Macroeconomic Statistics." Washington, DC.

Izaguirre, J. C., D. Dias and M. Kerse. 2019. "Deposit Insurance Treatment of E-money - an Analysis of Policy Choices." CGAP Technical Note, Washington, DC.

Jack, W. and T. Suri. 2011. "Mobile Money: The Economics of M-Pesa." NBER Working Paper No. 16721, National Bureau of Economic Research, Cambridge, MA.

Jack, W. and T. Suri. 2014. "Risk Sharing and Transactions Costs: Evidence from Kenya's Mobile Money Revolution." American Economic Review 104 (1): 183-223. 
Kerse, M. and S. Staschen. 2018. "Safeguarding Rules for Customer Funds held by EMIs." CGAP Technical Note, Washington, DC.

Khiaonarong, T. and D. Humphrey. 2019. "Cash Use across Countries and the Demand for Central Bank Digital Currency," IMF Working Paper No 19/46, International Monetary Fund, Washington, DC.

Kipkemboi, K. and K. Bahia. 2019. "The Impact of Mobile Money on Monetary and Financial Stability in Sub-Saharan Africa." GSMA Report, Global System for Mobile Communications, London.

Kireyev, A. P. 2017. "The Macroeconomics of De-cashing." IMF Working Paper No 17/71, International Monetary Fund, Washington, DC.

Mawejje, J. and P. Lakuma. 2019. "Macroeconomic Effects of Mobile Money: Evidence from Uganda." Financial Innovation 5 (23).

McKay, C. 2016. "Interest Payments on Mobile Wallets: Bank of Tanzania's Approach." CGAP Blog Series: Emerging Regulatory Enablers in Digital Financial Services, Washington, DC.

Monetary and Financial Statistics Manual and Compilation Guide. 2016. International Monetary Fund, Washington, DC.

Munyegera, G. K. and T. Matsumoto. 2016. "Mobile Money, Remittances, and Household Welfare: Panel Evidence from Rural Uganda." World Development 79: 127-137.

OECD. 2020. "Digital Economy Outlook 2020". Organisation for Economic Co-operation and Development, Paris.

Pelletier, A., S. Khavul and S. Estrin. 2019. "Regulating Mobile Money, what's at Stake." LSE Business Review, London School of Economics, London.

Pelletier, A., S. Khavul and S. Estrin. 2020. "Innovations in Emerging Markets: the Case of Mobile Money." Industrial and Corporate Change 29 (2): 395-421.

Reserve Bank of India. 2014. "Guidelines for Licensing of Payments Banks". Mumbai.

Riley, E. 2018. "Mobile Money and Risk Sharing against Aggregate Shocks." Journal of Development Economics 135: 43-58.

Suri, T. and W. Jack. 2016. "The Long-Run Poverty and Gender Impacts of Mobile Money." Science 354 (6317): 1288-1292.

Suri, T., J. Aker, C. Batista, M. Callen, T. Ghani, W. Jack, L. Klapper, E. Riley, S. Schaner, and S. Sukhtankar. 2021. "Mobile Money." VoxDevLit 2 (1).

Wasunna, N. and J. Frydrych. 2017. "Person-to-Government (P2G) Payment Digitization: Lessons from Kenya." GSMA Report, Global System for Mobile Communications, London. 


\section{Annex I. Data Sources for Mobile Money}

While the IMF's Financial Access Survey (FAS) provides supply-side annual country level data on mobile money, there are also other databases which cover a range of aspects including qualitative information on policies and higher frequency data at the individual country level. This annex summarizes such select data sources.

GSMA: The GSMA's annual Global Adoption Survey collects data from mobile money service providers and presents a set of mobile money metrics for six geographical regions, covering up to 90 countries. The GSMA does not however release data at an individual country level. This database includes annual data by region between 2001-19 on the number of mobile money services worldwide. It also contains quarterly data by region on the number of registered and active mobile money agents, the number of registered and active mobile money accounts, and the volume and value (in USD) of transactions processed by the industry across different products.

Country level data: Some have started to publish higher frequency country level data on mobile money. For example, the Bank of Zambia reports monthly data on mobile payment values and volumes since 2012. The Central Banks of Kenya, Uganda and Bangladesh also publish monthly data on a variety of mobile money series such as the number of active mobile money agents and the number of mobile money accounts. The Bank of Ghana also provides information on these mobile money features on an annual frequency.

Demand-side data: The World Bank Global Findex is a demand-side data source on financial inclusion. It was first released in 2012 and is updated triennially, covering 140 economies with data collected through sample surveys of roughly 1,000 people in each country. It covers 12 mobile money series, including gender disaggregated data on mobile money accounts.

Qualitative data: Some databases collect qualitative information on mobile money regulations and policies, providing useful information to supplement quantitative data in monitoring and understanding mobile money trends and developments:

- The GSMA Mobile Money Regulatory Index database provides information on the mobile money regulatory framework to help facilitate mobile money adoption for 90 countries where mobile money services are available. It contains 26 indicators to produce scores for six dimensions of mobile money regulation, which are aggregated into the overall index score. The six dimensions covered are (i) authorization; (ii) consumer protection; (iii) know your customer (KYC); (iv) agent network; (v) transaction limits; and (vi) infrastructure and investment environment. The index and indicators are scored ranging from 0 to 100, with a higher score associated with a more enabling regulatory framework.

- The GSMA Mobile Money Deployment Tracker monitors the number of live mobile money services globally using both primary and secondary sources on a monthly basis. It contains information on products offered by mobile money service providers as well as their partners in mobile money service provision. 
COVID-19 Policy Responses: The COVID-19 pandemic has created new data needs, including information on policies adopted in response to the pandemic. Digital financial services have been recognized as a useful tool in the pandemic context, and many countries have implemented policies to facilitate the use of digital financial services to support financial transactions while social distancing.

- The IMF's Financial Access COVID-19 Policy Tracker documents policy measures adopted in response to the pandemic across the globe, to support SME financing and usage of digital financial services, including mobile money. The information is collected from publicly available sources as well as feedback received from country authorities. The policy tracker categorizes policy responses aimed at promoting mobile money usage into three types: (i) temporary waiver of transaction fees; (ii) temporary increase of transaction and balance limits; and (iii) easing KYC onboarding requirements. ${ }^{25}$

- The GSMA's Mobile Money COVID-19 Regulatory Response Tracker contains information on mobile money specific interventions implemented to support mobile money customers and service providers during the pandemic. It covers a broader set of policy measures, including cash transfer programs using mobile money.

${ }^{25}$ See Bazarbash et al. (2020) for the details on the COVID-19 response measures related to mobile money and associated risks. 


\section{Annex II. Analysis of Transaction-level M-Pesa Data}

The FAS and GSMA data can offer insights into mobile money's development and trends at the country or regional level. However, due to lack of transaction-level data, little has been studied about individual mobile money usage patterns, which can provide more nuanced information about mobile money usage and help policymakers to design better targeted financial inclusion strategies. This annex reports the analysis of the transaction-level M-Pesa data which have been made publicly available by the Consultative Group to Assist the Poor (CGAP).

\section{Data and Methodology}

The CGAP has recently published transaction-level M-Pesa data for 418 low-income mobile money users living in Nairobi who gave consent to share anonymized mobile money transaction data and participated in a survey conducted by the Busara Center for Behavioral Economics. This open-source dataset contains the entire transaction history $(147,632$ transactions $)$ of these 418 low-income mobile money users from July 2017 to August 2018 . ${ }^{26}$ While the data may not be nationally representative, it provides useful insights into the use of mobile money in Kenya, especially the usage patterns and transaction volumes among low-income users.

The dataset includes seven different variables, including mobile money account ID numbers, encrypted phone numbers, receipt numbers, transaction details, transaction time, types, and values. It also provides information on transaction's nature, mobile money agent's location, and a detailed description of the transaction for each transaction entry. Using each account ID number and the encrypted phone number, which are unique to each account holder, the transaction history for each of the account holders in the dataset were recreated. Topic modeling - a machine learning technique-was applied to categorize transactions into eight categories. Then entity recognition, keyword extraction, and random-sampled human coding were used to refine and validate the categorization.

\section{Key Findings}

The anlayis found that 95 percent of the mobile money accounts were active during the sample period. ${ }^{27}$ The average balance on mobile money accounts is USD12.8, close to 9 percent of monthly income in Kenya. ${ }^{28}$ Transactions are categorized into the following eight categories (Table A.II.1):

- Person-to-Person (P2P) transactions: This category includes deposit and withdrawal of funds between users and the most popular function measured by transaction share

${ }^{26}$ The data are available at: https://www.cgap.org/blog/how-do-kenyans-really-use-m-pesa.

${ }^{27}$ Active mobile money accounts are defined as those used to conduct a mobile money transfer or cash-in cash-out transaction over the past 90 days, in line with the FAS guidelines.

${ }^{28}$ Monthly income is approximated by GNI per capita per month. The GNI per capita in Kenya was USD 1,750 in 2019 according to the World Bank. 
(28 percent of all transactions). The average value of $\mathrm{P} 2 \mathrm{P}$ transactions ranges from USD 5 to USD 7.

- Business-to-Person/Person-to-Business (B2P/P2B) transactions: This covers transactions from and to business enterprises, including vendors, merchants, and companies, accounting for the second-highest share in total transaction. However, the degree of usage varies across subcategories. About 79 percent of the users in the sample have used mobile money to pay bills using M-Pesa while only 20 percent of these users received salary payments via M-Pesa. The average value of salary payments is higher than other catogries, at about USD 24.

- Airtime purchase: This refers to the purchase made for phone calls, SMS, or cellular data usage. Airtime cannot be used as money to purchase other items or pay bills. ${ }^{29}$

- Deposit and withdrawal of funds: This category is the most basic function of mobile money together with the $\mathrm{P} 2 \mathrm{P}$ function, accounting for 18 percent of all transactions and used by almost all users in the sample. The average values of the deposit and withdrawal of funds are around USD 12.

- Transaction fees: These are charges collected by the telecommunication operators for mobile money transactions. Whereas all deposits are free, M-Pesa charges for sending and withdrawing money through a Safaricom agent, ATMs, and transferring cash to registered and non-registered M-Pesa accounts. Specific charges depend on the amount of withdrawal and transfers. ${ }^{30}$ Nearly all account holders were once charged for transaction fees. The average transaction fees across all charges is about USD 0.3 .

- Financial Derivatives: This category includes any additional financial services provided by the partnering commercial banks in Kenya. Commercial Bank of Africa (CBA) and KCB Bank Kenya Limited allow M-Pesa users to open deposit accounts via M-Pesa and transfer mobile money balance to earn interests. Not only the basic saving accounts, but both KCB and M-Shwari also provide micro-credit loan products, which allows M-Pesa subscribers to borrow money in times of need and to fund a project or enterprise. Borrowing via M-Pesa derivatives can help users build their credit history to facilitate future financing. Noticeably, around 40 percent of the users in the sample have utilized these basic savings accounts with the average value of M-Shwari/KCB M-Pesa deposits standing at USD17, slighlty higher than the average value of regular deposits in M-Pesa. These findings show that M-Pesa users now have increased options to save and borrow funds using mobile money.

- International Transfers: This refers to international remittances received via an international money transfer service provider. Although the share of international transfers in all transactions is small at 0.02 percent, the average value of such transfers is USD $85-$

29 https://www.worldremit.com/en/faq/mobile-money\#13873

${ }^{30}$ Details on M-Pesa rates are available at https://www.safaricom.co.ke/personal/m-pesa/gettingstarted/m-pesa-rates. 
about 60 percent of average monthly income in Kenya-substantially higher than any other category.

- Others: This includes transactions not categorzied into the seven categories aforementioned.

Table A.Il.1. Mobile Money Transaction-Level Data

\begin{tabular}{|c|c|c|c|c|c|c|c|}
\hline Category & $\begin{array}{l}\text { Category } \\
\text { Share in all } \\
\text { Transactions } \\
\text { (percent) }\end{array}$ & $\begin{array}{l}\text { Transaction } \\
\text { Types }\end{array}$ & $\begin{array}{l}\text { Number of } \\
\text { Transactions }\end{array}$ & $\begin{array}{l}\text { Share of all } \\
\text { Transactions } \\
\text { (percent) }\end{array}$ & $\begin{array}{l}\text { Usage: } \\
\text { Number } \\
\text { of } \\
\text { Accounts }\end{array}$ & $\begin{array}{l}\text { Usage: } \\
\text { Share of } \\
\text { Total } \\
\text { Accounts } \\
\text { (percent) }\end{array}$ & $\begin{array}{l}\text { Average } \\
\text { Value } \\
\text { (USD) }\end{array}$ \\
\hline \multirow{2}{*}{$\begin{array}{l}\text { P2P } \\
\text { Transactions }\end{array}$} & \multirow{2}{*}{28.07} & $\begin{array}{l}\text { Customer } \\
\text { transfer }\end{array}$ & 23501 & 15.92 & 401 & 95.93 & 5.11 \\
\hline & & $\begin{array}{l}\text { Funds } \\
\text { received }\end{array}$ & 17932 & 12.15 & 411 & 98.33 & 8.71 \\
\hline \multirow{3}{*}{$\begin{array}{l}\text { B2P/P2B } \\
\text { Transactions }\end{array}$} & \multirow{3}{*}{22.56} & Pay Bill & 29320 & 19.86 & 327 & 78.23 & 1.33 \\
\hline & & $\begin{array}{l}\text { Other } \\
\text { Payment }\end{array}$ & 3679 & 2.49 & 287 & 68.66 & 9.4 \\
\hline & & $\begin{array}{l}\text { Salary } \\
\text { Payment }\end{array}$ & 312 & 0.21 & 85 & 20.33 & 24.36 \\
\hline $\begin{array}{l}\text { Airtime } \\
\text { Purchase }\end{array}$ & 18.96 & $\begin{array}{l}\text { Airtime } \\
\text { purchase }\end{array}$ & 27992 & 18.96 & 410 & 98.09 & 0.29 \\
\hline \multirow{2}{*}{$\begin{array}{l}\text { Deposit and } \\
\text { Withdrawal of } \\
\text { Funds }\end{array}$} & \multirow{2}{*}{18.02} & $\begin{array}{l}\text { Customer } \\
\text { withdrawal }\end{array}$ & 13622 & 9.23 & 416 & 99.52 & 13.24 \\
\hline & & $\begin{array}{l}\text { Deposit of } \\
\text { funds }\end{array}$ & 12977 & 8.79 & 406 & 97.13 & 11.69 \\
\hline $\begin{array}{l}\text { Transaction } \\
\text { Fees }\end{array}$ & 8.57 & $\begin{array}{l}\text { Withdrawal } \\
\text { charge }\end{array}$ & 12645 & 8.57 & 416 & 99.52 & 0.29 \\
\hline \multirow{4}{*}{$\begin{array}{l}\text { Financial } \\
\text { Derivatives }\end{array}$} & \multirow{4}{*}{3.44} & $\begin{array}{l}\text { M- } \\
\text { Shwari/KCB } \\
\text { Withdraw }\end{array}$ & 2736 & 1.85 & 177 & 42.34 & 8.11 \\
\hline & & $\begin{array}{l}\text { M- } \\
\text { Shwari/KCB } \\
\text { Deposit } \\
\end{array}$ & 1230 & 0.83 & 164 & 39.23 & 17.25 \\
\hline & & $\begin{array}{l}\text { M- } \\
\text { Shwari/KCB } \\
\text { Loan } \\
\end{array}$ & 954 & 0.65 & 102 & 24.40 & 0.39 \\
\hline & & $\begin{array}{l}\text { M-Shwari } \\
\text { Lock } \\
\text { Deposit }\end{array}$ & 164 & 0.11 & 19 & 4.55 & 6.22 \\
\hline Others & 0.36 & Others & 532 & 0.36 & 187 & 44.74 & 1.24 \\
\hline $\begin{array}{l}\text { International } \\
\text { Transfers }\end{array}$ & 0.02 & $\begin{array}{l}\text { International } \\
\text { Transfers }\end{array}$ & 36 & 0.02 & 10 & 2.39 & 84.92 \\
\hline
\end{tabular}

Source: IMF staff calculations from CGAP data.

Note: "Usage: Share of total accounts" shows the share of accounts used for a specific type of transactions in total accounts. For example, if it is 100 percent for a certain category of transactions, then it means that all accounts in the sample had at least one transaction under the category. 
Annex III. SRFs and Compilation of Monetary Aggregates under the MFSMCG

The chart below complements the discussion in Box 4, summarizing the use of SRFs and the compilation of monetary aggregates under the MFSMCG framework.
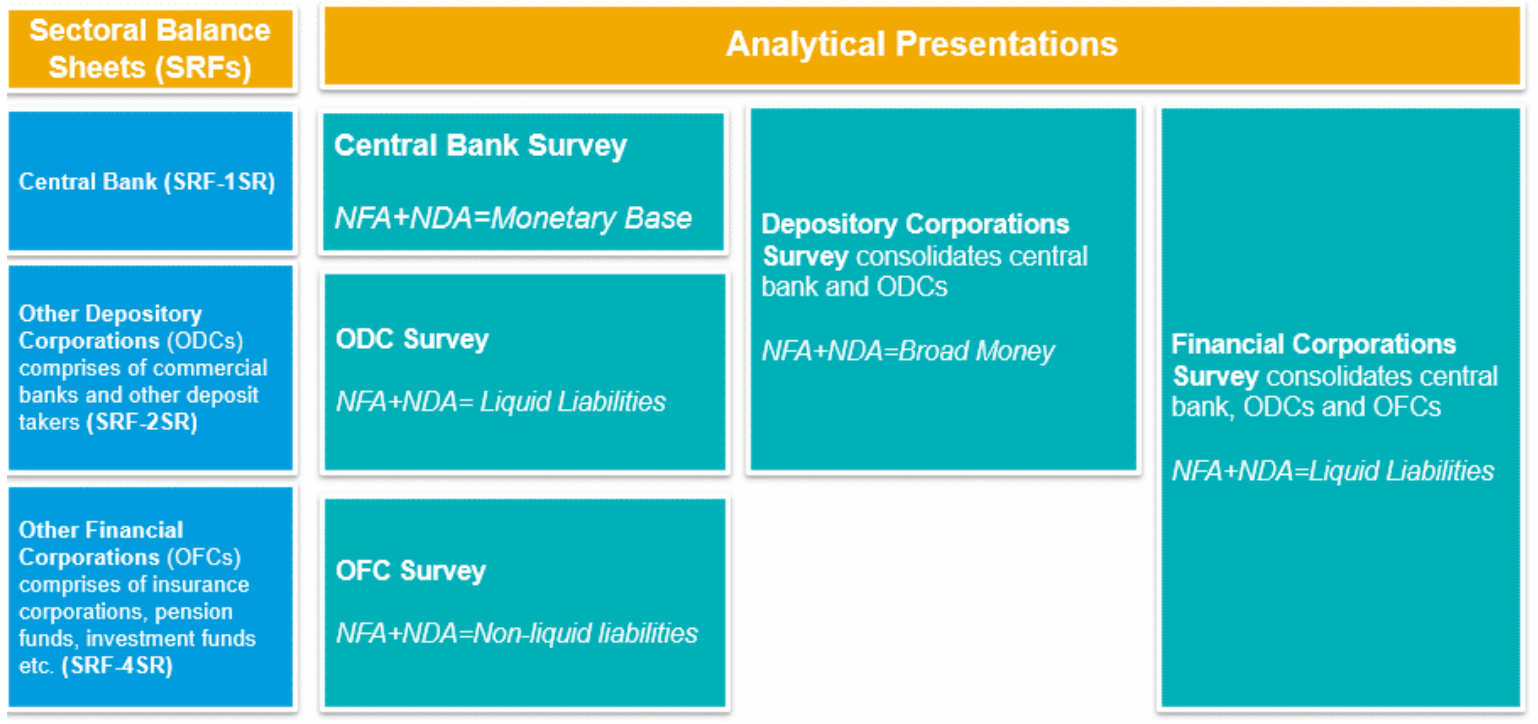

Source: IMF staff and the MFSMCG.

$N F A=$ Net Foreign Assets and NDA=Net Domestic Assets. 


\section{Annex IV. IMF's Monetary and Financial Statistics Database}

The monetary and financial statistics (MFS) database contains in addition to the monetary aggregates, key credit aggregates like credit to the private sector by the banking system or the claims of the central bank on the central government. The visualization tools embedded in the database allow quick analysis of these credit aggregates for over 170 countries. An interactive map allows users to compare broad-money growth for countries across the globe over the years. Many of these countries are also using the SRFs as the platform to generate the monetary data disseminated through their national publications

In fact, the MFS database has several presentations of monthly SRF based monetary data dating back to 2001 that provide a framework for analyzing the relationship between the FCs sector and other institutional sectors, including broad money, credit aggregates, and liquidity measures for example, with net domestic assets as a correspondent to broad money. These analytical presentations of monetary data are presented separately for the central bank, the ODCs, and the OFCs. The database also presents consolidated data for the depository corporations (also known as monetary survey) and the entire financial corporations' sector.

More than 40 countries have agreed to disseminate detailed monetary data based on the SRFs through the MFS database. These SRF data provide the asset and liability positions (and the corresponding flows) that are presented in a balance-sheet-like form by category of financial instrument, by currency (domestic and foreign), and by counterpart institutional sector.

Most countries compile the central bank and ODC data on a monthly basis and report it within one or two months after the end of the reference period. OFC data are sometimes submitted quarterly.

The MFS database also contains monetary data on non-SRF countries, namely those that have not adopted the MFSMCG methodology in compiling monetary data reported to the IMF. 